\title{
Meta-analysis of northeast Atlantic marine taxa shows contrasting phylogeographic patterns following post-LGM expansions
}

\author{
Tom L Jenkins ${ }^{1}{ }^{\text {, Rita Castilho }}{ }^{2}{ }^{\text {, Jamie R Stevens }}{ }^{\text {Corresp. }}{ }^{1}$ \\ 1 Department of Biosciences, University of Exeter, Exeter, United Kingdom \\ 2 Center for Marine Sciences, Campus de Gambelas, University of Algarve, Faro, Portugal \\ Corresponding Author: Jamie R Stevens \\ Email address: j.r.stevens@ex.ac.uk
}

\section{Background}

Comparative phylogeography enables the study of historical/evolutionary processes that have contributed to shaping patterns of contemporary genetic diversity across co-distributed species. In this study, we explored genetic structure and historical demography in a range of coastal marine species across the northeast Atlantic to assess whether there are commonalities in phylogeographic patterns across taxa and to evaluate whether the timings of population expansions were linked to the Last Glacial Maximum (LGM).

\section{Methods}

A literature search was conducted using Web of Science. Search terms were chosen to maximise the inclusion of articles reporting on population structure and phylogeography from the northeast Atlantic; titles and abstracts were screened to identify suitable articles within the scope of this study. Given the proven utility of mtDNA in comparative phylogeography and the availability of these data in the public domain, a meta-analysis was conducted using published mtDNA gene sequences. A standardised methodology was implemented to ensure that the genealogy and demographic history of all mtDNA datasets were reanalysed in a consistent and directly comparable manner.

\section{Results}

Mitochondrial DNA datasets were built for 21 species. The meta-analysis revealed significant population differentiation in 16 species and four main types of haplotype network were found, with haplotypes in some species unique to specific geographical locations. A signal of rapid expansion was detected in 16 species, whereas five species showed evidence of a stable population size. Corrected mutation rates indicated that the majority of expansions were estimated to have occurred after the earliest estimate for the LGM ( 26.5 Kyr), while few expansions were estimated to have pre-dated the LGM.

\section{Conclusion}

This study suggests that post-LGM expansion appeared to be common in a range of marine taxa, supporting the concept of rapid expansions after the LGM as the ice sheets started to retreat. However, despite the commonality of expansion patterns in many of these taxa, phylogeographic patterns appear to differ in the species included in this study. This suggests that species-specific evolutionary processes, as well as historical events, have likely influenced the distribution of genetic diversity of marine taxa in 
the northeast Atlantic. 
1 Meta-analysis of northeast Atlantic marine taxa shows contrasting phylogeographic

2 patterns following post-LGM expansions

3

4 Tom L. Jenkins ${ }^{1}$, Rita Castilho² ${ }^{2}$ Jamie R. Stevens ${ }^{1}$

$5{ }^{1}$ Department of Biosciences, College of Life and Environmental Sciences, University of Exeter,

6 Exeter, EX4 4QD, UK

$7{ }^{2}$ Center for Marine Sciences, University of Algarve, Campus de Gambelas, 8005-139 Faro,

8 Portugal

9

10 Corresponding authors:

11 Jamie R. Stevens, J.R.Stevens@exeter.ac.uk

12 Tom L. Jenkins, t.1.jenkins@exeter.ac.uk

13

14 ORCID ID:

15 Tom L. Jenkins: https://orcid.org/0000-0001-5774-0278

16 Jamie R. Stevens: https://orcid.org/0000-0002-1317-6721 


\section{Abstract}

\section{Background}

19 Comparative phylogeography enables the study of historical/evolutionary processes that have

20 contributed to shaping patterns of contemporary genetic diversity across co-distributed species.

21 In this study, we explored genetic structure and historical demography in a range of coastal

22 marine species across the northeast Atlantic to assess whether there are commonalities in

23 phylogeographic patterns across taxa and to evaluate whether the timings of population

24 expansions were linked to the Last Glacial Maximum (LGM).

\section{Methods}

27 A literature search was conducted using Web of Science. Search terms were chosen to maximise

28 the inclusion of articles reporting on population structure and phylogeography from the northeast

29 Atlantic; titles and abstracts were screened to identify suitable articles within the scope of this

30 study. Given the proven utility of mtDNA in comparative phylogeography and the availability

31 of these data in the public domain, a meta-analysis was conducted using published mtDNA gene

32 sequences. A standardised methodology was implemented to ensure that the genealogy and

33 demographic history of all mtDNA datasets were reanalysed in a consistent and directly

34 comparable manner.

35

\section{Results}

37 Mitochondrial DNA datasets were built for 21 species. The meta-analysis revealed significant 38 population differentiation in 16 species and four main types of haplotype network were found,

39 with haplotypes in some species unique to specific geographical locations. A signal of rapid 
40 expansion was detected in 16 species, whereas five species showed evidence of a stable

41 population size. Corrected mutation rates indicated that the majority of expansions were

42 estimated to have occurred after the earliest estimate for the LGM ( $26.5 \mathrm{Kyr})$, while few

43 expansions were estimated to have pre-dated the LGM.

44

\section{Conclusion}

46 This study suggests that post-LGM expansion appeared to be common in a range of marine taxa,

47 supporting the concept of rapid expansions after the LGM as the ice sheets started to retreat.

48 However, despite the commonality of expansion patterns in many of these taxa, phylogeographic

49 patterns appear to differ in the species included in this study. This suggests that species-specific

50 evolutionary processes, as well as historical events, have likely influenced the distribution of

51 genetic diversity of marine taxa in the northeast Atlantic. 


\section{Introduction}

53 Comparative phylogeographic studies present opportunities to explore how historical events may

54 have helped shape patterns of genetic structure amongst co-distributed species (Avise et al.,

55 1987; Avise, 2009; Hickerson et al., 2010). Patterns of concordant phylogeographical structure

56 across multiple taxa are particularly informative because, while some patterns of spatial genetic

57 structure may be caused by species-specific evolutionary processes, patterns common across

58 multiple taxa may suggest similar evolutionary histories, such as common barriers to gene flow

59 (Avise, 2009; Hickerson et al., 2010). These findings can be important for conservation because

60 of the potential to modify management actions in the light of the differing phylogeography of

61 multiple species across the same geographical area (Pelc, Warner \& Gaines, 2009; Toonen et al.,

62 2011; Heyden et al., 2014; Liggins et al., 2016). In marine biology, such comparative studies

63 have made important contributions to our understanding of how historical events, such as the

64 Pleistocene glaciations, have helped shape the spatial patterns of contemporary genetic diversity

65 of marine taxa (Patarnello, Volckaert \& Castilho, 2007; Maggs et al., 2008; Marko et al., 2010;

66 Ni et al., 2014).

67 The Pleistocene epoch was characterised by recurrent glaciations and intensive

68 fluctuations in climate that periodically influenced the spatial distributions of plants and animals

69 (Hewitt, 1999; Hofreiter \& Stewart, 2009). The most recent glacial period began approximately

$70115 \mathrm{Ka}$ and nearly all ice sheets were at their maximum (Last Glacial Maximum, LGM) between

71 26.5-19 Ka (Clark et al., 2009). The advances of the Northern Hemisphere ice sheets led to

72 significant changes in temperature and sea levels (Lambeck \& Chappell, 2001). This must have

73 had profound implications for habitat availability and the population persistence of coastal

74 species - large parts of species' ranges would have been reduced, while other species may have 
75 survived in glacial refugia (Maggs et al., 2008; Provan \& Bennett, 2008). As the ice retreated

76 and the sea level rose, a number of individuals from refugial populations may have dispersed and

77 recolonised areas unavailable during the glaciation (Hewitt 2000). Changes in latitudinal ranges

78 and population sizes can have distinct effects on the genetic architecture of a species due to the

79 competing processes of mutation, drift and selection; moreover, the deep molecular divergence

80 reported in taxa associated with several known European refugia suggests repeated expansion

81 and contraction of conspecific populations were common throughout the Pleistocene (Hewitt,

82 2004).

83 In the northeast Atlantic, it is thought that the ice sheets extended as far south as the

84 British Isles, leaving an ice-free zone in mid-southern England, with possibly a small area in

85 southwest Ireland free of ice (Chiverrell \& Thomas, 2010). However, the predicted extent of ice

86 coverage across southern Ireland and the Celtic Sea differs among studies (e.g. Taberlet et al.,

87 1998; Hughes et al., 2016). The advance of the ice sheets led to a drastic drop in sea levels in the

88 English Channel, resulting in the complete emersion of the channel between England and France,

89 except for a palaeo-river that extended across the continental margin (Ménot et al., 2006). This

90 suggests that extant coastal communities inhabiting these areas are likely recolonisers originating

91 from glacial refugia. It has been suggested that Hurd Deep, a trench in the English Channel (Fig.

92 1), might have persisted as a marine lake during the LGM, thereby acting as a potential glacial

93 refugium (Provan, Wattier \& Maggs, 2005; Hoarau et al., 2007). Other areas further south,

94 including Brittany (Coyer et al., 2003) and the Iberian Peninsula (Hoarau et al., 2007; Neiva et

95 al., 2012) (Fig. 1), have also been postulated to act as refugia during the LGM. This was

96 supported by high levels of genetic diversity found at these areas in the species studied, a key

97 signature indicative of glacial refugia (Provan \& Bennett, 2008). 
Studies of single-species phylogeography across the northeast Atlantic are common; yet,

99 because of the differences in molecular methodologies and analytical approaches, it can be difficult to compare results reliably. By applying a consistent methodology across all studies,

101

102

103

104 106 area characterised by complex oceanography and historical biogeographical events, such as the

117 Pleistocene glaciations. Specifically, our aims were: (i) to identify commonalties (or otherwise) 118 in contemporary genetic structure; (ii) to re-examine historical demography to test for signatures 119

this standardises the analysis (Harrison, 2011), enabling patterns of phylogeography to be explored and compared within and across taxa. Two comparative meta-analyses in the Atlantic Ocean have been published to-date: the first explored the feasibility of distinguishing genetic signatures of periglacial refugia from southern refugia in eight benthic marine species (Maggs et al., 2008), and the second looked for concordance among phylogeographical breaks around the southeast coast of the United States of America (Pelc, Warner \& Gaines, 2009). Systematic meta-analyses across diverse taxa in other seas/oceans have proved useful for exploring broad patterns of phylogeography (e.g. Patarnello, Volckaert \& Castilho, 2007; Kelly \& Palumbi, 2010; Marko et al., 2010; Ni et al., 2014); for example, one study of rocky-shore taxa from the northeastern Pacific found that $36 \%$ of species showed evidence of population expansions associated with the LGM, while $50 \%$ exhibited demographic patterns consistent with stable effective population sizes (Marko et al., 2010). However, such a study for marine taxa across the northeast Atlantic has yet to be undertaken.

In this study, we reanalyse available mitochondrial (mt)DNA data to compare the phylogeography of coastal benthic/demersal organisms across the northeast Atlantic (Fig. 1), an of population expansions; and (iii) to estimate the timings of any expansions detected. We 
120 discuss our findings in the context of the Pleistocene glaciations, asking in particular whether the 121 LGM affected the phylogeography of marine taxa concordantly or discordantly. 


\section{Materials and methods}

\section{Literature search}

124 To compare the phylogeography of benthic and demersal organisms across the northeast

125 Atlantic, we undertook a meta-analysis of molecular phylogeographic studies. A literature

126 search was conducted by TLJ and JRS using Web of Science (Thomson Reuters) in February

127 2015. Search terms were chosen to maximise the inclusion of articles reporting on population

128 structure and phylogeography from the northeast Atlantic. The following sets of Boolean search

129 terms were submitted to the Advanced Search Tool: (1) gene flow OR population structure OR

130 genetic diversity OR phylogeograph*; (2) marine OR intertidal OR subtidal OR estuar*; and (3)

131 Atlantic. Titles and abstracts were screened by TLJ and JRS to identify suitable articles within

132 the scope of this study and only articles that matched the following criteria were retained: (a)

133 organisms were fully marine or estuarine throughout their life history (diadromous species were

134 excluded); (b) studies of temporal changes, hybridisation or introgression from closely related

135 species were omitted; (c) the study included at least three sampling sites from within the

136 northeast Atlantic (Fig. 1 - sites outside of this area were not considered); (d) datasets contained

137 a minimum of five individuals per site and a total sample size of at least 50; and (e) the study

138 included latitude and longitude of the sampling sites or a detailed description or map which

139 provided sufficient detail to determine the geographical location of sample origins. The

140 studies/datasets for inclusion in the analysis were reviewed independently by TLJ and JRS and

141 there were no disputes regarding inclusion or rejection that needed adjudication. Given the

142 proven utility of mtDNA in comparative phylogeography (e.g. Patarnello, Volckaert \& Castilho,

143 2007; Ni et al., 2014) and the availability of these data in the public domain, a meta-analysis was

144 conducted using published mtDNA gene sequences. 
146 Data reanalysis

147 A standardised methodology was implemented to ensure that all mtDNA datasets were

148 reanalysed in a consistent and directly comparable manner. Data analyses in the original studies

149 were far from consistent, particularly with respect to the analysis of haplotype networks and

150 historical demography. The majority of studies reported information about population structure,

151 however, in several instances the studies included additional samples outside of the northeast

152 Atlantic in their analysis. Therefore, standardised tests of population structure were undertaken

153 de novo for each species. Sites that were genetically homogeneous (as described by the original

154 authors) and which were spatially close or situated in the same geographical region were

155 combined in some datasets. This ensured that phylogeography within and across seas was

156 examined in this meta-analysis. Population differentiation was examined using global values of

157 Jost's $D$ (Jost, 2008) and $F_{\mathrm{ST}}$ (Weir \& Cockerham 1984) using the fastDivPart function from the 158 R package diveRsity (Keenan et al., 2013; R Core Team, 2016) and significance was assessed 159 using 10,000 permutation replicates.

160 To examine the genealogical relationships within species, haplotype networks were 161 constructed using the haploNet function from the R package pegas (Paradis, 2010). Tajima's $D$

162 (Tajima, 1989), Fu's $F_{\mathrm{S}}(\mathrm{Fu}, 1997)$ and Ramos-Onsins' $R_{2}$ (Ramos-Onsins and Rozas 2002)

163 neutrality tests were performed in DnaSP v5.10 (Librado \& Rozas 2009) to determine whether

164 each species carried a signal that deviated from neutrality (significance was assessed using

16510,000 bootstrap replicates). Mismatch analyses (frequency of pairwise nucleotide-site

166 differences between sequences) were carried out using the population growth-decline model in

167 DnaSP to further examine the demographic history and Harpending's raggedness index $(r)$ 
168 (Harpending, 1994) was used to evaluate the fit of the observed distribution to the growth169 decline model (10,000 bootstrap replicates). A non-significant index suggests that the observed

170 data have a relatively good fit to the growth-decline model. In contrast, a significant index is

171 indicative of a stable population which is typically thought to show a 'ragged', multi-modal 172 mismatch (Harpending, 1994).

173 The equation $t=\tau /(2 \mu k)$ was used to estimate the timing of a population expansion $(t)$,

174 where $\tau$ is the date of the expansion measured in units of mutational time (Tau - estimated using 175 DnaSP), $\mu$ is the mutation rate per site per year and $k$ is the sequence length. In addition, 176 Bayesian Skyline Plots (BSPs) were run using BEAST2 v2.5.0 (Drummond et al., 2005;

177 Bouckaert et al., 2014). BEAST2 uses a Markov chain Monte Carlo (MCMC) sampling

178 procedure to estimate effective population size $\left(N_{\mathrm{e}}\right)$ through time based on the temporal

179 distribution of coalescences in gene genealogies. For each dataset, the substitution model was

180 selected using bModelTest (Barido-Sottani et al., 2018), which uses reversible jump MCMC that

181 allows the Markov chain to jump between states representing different possible substitution

182 models. A strict clock and a coalescent Bayesian Skyline prior was implemented. Each run

183 consisted of 100 million steps with a burn-in of one million and parameters were sampled every

184 10,000 steps. Chain convergence and BSPs were analysed with Tracer v1.7.1 (Rambaut et al., 185 2018).

Recent studies have shown that the use of mutation rates derived from ancient calibration

187 dates and/or inferred from phylogenetic analyses may not be appropriate for studies at the 188 population level (Ho et al., 2008, 2011). In this study, therefore, mutation rates were chosen

189 based on the most recent calibration date available for the closest taxonomic relative (Table S1, 190 Supplementary Information). In published studies where a mutation rate was not specified, the 
191 genetic distance provided by the study was divided by the date of the calibration event (in Myr)

192 to obtain a \% mutation rate per Myr. For cases where only calibration dates older than $5 \mathrm{Myr}$

193 were available for the species and gene of interest, a three-fold correction in mutation rate was

194 applied to the original rate to control for the potential time-dependency of molecular rates. This

195 adjustment was implemented because rates have been found to vary by three to six-fold for

196 several marine species when calibration dates younger than $5 \mathrm{Myr}$ vs. older dates have been

197 tested (Crandall et al., 2012; Laakkonen, Strelkov \& Väinölä, 2015). A range of mutation rates

198 based on the rates reported by previous studies were used to calculate a minimum, maximum and

199 average time estimate since a population expansion.

200

201 Results

202 Literature search

203 The initial search using Boolean terms identified 1,120 articles, which was reduced to 56 articles

204 after the titles and abstracts were examined and the search criteria were applied (Fig. S1,

205 Supplementary Information). The final database for the meta-analysis consisted of mtDNA gene

206 sequence data from 21 studies (Table 1); some studies from the previous step were not included

207 due to the use of RFLPs in mtDNA or because some mtDNA datasets were not publicly

208 available. The final database spanned several taxonomic groups, with fishes, molluscs and

209 crustaceans accounting for the majority of species (81\%). The most common mitochondrial

210 gene across all studies was cytochrome oxidase I (COI), followed by cytochrome $b$ (Cyt $b$ ), the

211 control region (CR) and the intergenic spacer region (IGS). COI was the most commonly used

212 gene for invertebrate studies, IGS for macroalgae, and studies of fish used either the CR or the

213 Cyt $b$ gene. 


\section{Genetic structure}

216 Sixteen species showed significant global Jost's $D$ and $F_{\mathrm{ST}}$ values, indicative of population

217 differentiation (Table 2), while the remaining five species showed little evidence of population

218 differentiation. Across the 21 datasets, four different types of haplotype network were putatively

219 identified based on the structure of the networks (Fig. 2) (all haplotype networks are presented in

220 Fig. S2, Supplementary Information):

221 (i) A 'Star' network (Fig. 2a), in which a single, widespread haplotype is typically

222 positioned at the centre of the network and is thought to be the ancestral haplotype. Additional

223 haplotypes are linked to this dominant haplotype by a single (or a few) mutational step(s),

224 suggesting these haplotypes are the product of recent mutation events. Eight species showed this 225 type of relationship (Celleporella hyalina, Conger conger, Nassarius nitidus, Nassarius

226 reticulatus, Palinurus elephas, Pelvetia canaliculata, Pomatoschistus microps and Raja clavata).

227 In one case, the dominant haplotype had far fewer connections than a low-frequency haplotype

228 in the network, making it difficult to distinguish the centre of the network with confidence

229 (Pomatoschistus microps);

230 (ii) A 'Complex star' network (Fig. 2b), in which there are multiple high-frequency

231 haplotypes and connections. Six species showed this type of relationship (Carcinus maenus,

232 Cerastoderma edule, Maja brachydactyla, Pomatoschistus minutus, Solea solea, Symphodus

233 melops);

234 (iii) A 'Reciprocally monophyletic' network (Fig. 2c), in which more than one lineage is 235 apparent and each lineage is linked by a long branch associated with numerous mutations. Four 236 species showed this type of relationship (Macoma balthica, Modiolus modiolus, Owenia 237 fusiformis and Pectinaria koreni); 
(iv) A 'Complex mutational' network (Fig. 2d), in which some branches were separated

239 by a very large number of mutations, while other branches had contrarily one or two mutations.

240 Three species showed this type of relationship (Dicentrarchus labrax, Labrus bergylta and

241 Neomysis integer). In most cases, a dominant haplotype was present and was presumed to be the

242 ancestral form. However, Neomysis integer presented an unusual network in which a distinct

243 ancestral haplotype was not apparent and the centre of the haplotype network was not readily

244 distinguishable.

245

\section{Historical demography}

247 Historical demography was inferred for each species based on the observed mismatch

248 distribution, neutrality tests and the raggedness index (Table 2). Four main types of mismatch

249 distributions were observed: unimodal, skewed unimodal, multimodal and bimodal (Fig. 3) (all

250 mismatch distributions are presented in Fig. S3, Supplementary Information). Unimodal is

251 associated with a sudden population expansion (e.g. Maja brachydactyla; Fig. 3a), and skewed

252 unimodal is generally associated with a recent expansion or bottleneck (e.g. Nassarius

253 reticulatus; Fig. 3b). Multimodal (e.g. Labrus bergylta; Fig. 3c) and bimodal (e.g. Macoma

254 balthica; Fig. 3d) are usually associated with constant population size. However, previous

255 research has suggested that bimodal peaks may indicate the presence of two distinct lineages

256 (e.g. Alvarado Bremer et al. 2005), which would potentially violate the assumptions of

257 coalescent theory if analysed as one 'genetic' population. In this case, the first peak would

258 represent intra-clade pairwise differences, whereas the second peak would likely represent more

259 ancient inter-clade pairwise differences (Fig. 3d). For each instance of bimodality, the haplotype

260 network was inspected for evidence of two or more lineages. The networks indicated that more 
261 than one distinct lineage was evident for all bimodal mismatches (Macoma balthica, Modiolus

262 modiolus, Owenia fusiformis and Pectinaria koreni) and, therefore, mismatch analysis and

263 neutrality tests were carried out on each lineage separately. These analyses were not conducted

264 for lineage 2 of Modiolus modiolus due to the small number of individuals $(N=3)$ comprising

265 this lineage.

266 Neutrality statistics for testing the drift-mutation equilibrium $\left(D, F_{\mathrm{S}}\right.$ and $\left.R_{2}\right)$ were found

267 to be contrasting between species (Table 2). These tests tended to be significant for species that

268 showed a star-shaped network and for which the mismatch graph was unimodal or skewed

269 unimodal. This supported evidence that a signal of rapid population expansion was detected;

270 however, a selective sweep can also produce the same genetic signal. Harpending's $r$ suggested

271 that two datasets departed from a model of demographic expansion (Table 2), but inspection of

272 the mismatch graphs and neutrality tests indicated there was strong evidence to support a rapid

273 population expansion (or selective sweep) in both datasets. No signatures of rapid population

274 expansion were detected in five species (Celleporella hyalina, Macoma balthica, Nassarius

275 nitidus, Neomysis integer and Raja clavata), suggesting a stable constant population size.

276 For the remaining 19 datasets (16 species, 19 including lineages), a historic population

277 expansion was assumed and the timing of the expansion was estimated (Fig. 4). All expansions

278 were found to take place during the Pleistocene or the Holocene epoch. Estimated timings for 17

279 datasets were after or overlapped the earliest estimate for the LGM ( 26.5 Ka). Expansion

280 estimates for one fish (Labrus bergylta) and one lineage of the polychaete Owenia fusiformis

281 pre-dated the LGM but were still positioned during the last glacial period. Bayesian Skyline

282 Plots (Fig. 5) were generally consistent with the results from the mismatch analyses. Among the

28317 datasets for which from the mismatch analyses expansion times were estimated to have 
284 occurred after the LGM, a rise in $N_{\mathrm{e}}$ post-LGM was apparent in 15 of these datasets, but the 285 strength of the increase varied across datasets. In comparison to the mismatch analysis, the BSP 286 for L. bergylta (Fig. 5f) and O. fusiformis lineage 2 (Fig. 5p) indicated a population expansion 287 after the earliest estimate for the LGM as oppose to pre-dating the LGM. In addition, although 288 the mismatch analyses inferred a post-LGM expansion for M. modiolus lineage 1 (Fig. 5m) and 289 O. fusiformis lineage 3 (Fig 5q), BSPs generally suggested $N_{\mathrm{e}}$ was constant after the LGM.

\section{Discussion}

292 The results of this study show a range of contemporary genetic patterns across the coastal marine 293 taxa analysed in the northeast Atlantic. In general, genealogical patterns were not uniform within 294 taxonomic groups, though common patterns were observed in both polychaete species, which 295 implies that historical events may have affected these polychaete species similarly. Most species 296 ( $76 \%$ ) showed evidence of population structuring, suggestive of restricted contemporary or

297 historical gene flow between the sites studied. Of the species that exhibited no population 298 differentiation, all five species have a pelagic larval phase, with a pelagic larval duration (PLD) 299 ranging from up to three weeks (S. solea) to a year or more (P. elephas and C. conger) (Table 1). 300 However, most of the species that demonstrated significant population differentiation also had a 301 pelagic larval phase, ranging from a relatively short PLD of 1-4 hour (C. hyalina) to a relatively

302 long PLD of 8-12 weeks (D. labrax) (Table 1). Although speculative, taken altogether, this may 303 suggest that larval development and PLD could be important factors in maintaining gene flow in 304 some, but not all, of these species; however, more evidence is needed to confirm this. Indeed, 305 whether a general correlation exists between PLD and genetic differentiation measures remains 306 unclear because some studies have reported poor correlations between the two (Weersing \& 
307 Toonen, 2009; Kelly \& Palumbi, 2010; Riginos et al., 2011), while other studies have reported

308 the opposite (Siegel et al., 2003; Selkoe \& Toonen, 2011) suggesting that PLD and genetic

309 metrics can indeed reflect scales of dispersal if the sampling design is robust (Selkoe \& Toonen,

310 2011). As a result, speculative relationships between PLD and genetic differentiation should be

311 interpreted with caution.

312 In some of the species studied, certain geographical areas were dominated by a particular

313 haplotype that was rarely or not present in other areas across the sampled range. For example,

314 the green crab Carcinus maenas showed highly significant differentiation and distinctive

315 haplotypes in the Faroe Islands and Iceland, a pattern detected by the original authors who

316 subsequently concluded that a deep-water barrier to dispersal in green crabs was the driver of

317 this pattern (Roman \& Palumbi, 2004). A similar pattern was also observed for two species

318 around western Ireland in the northeast Atlantic. In Celleporella hyalina and Macoma balthica,

319 distinct haplotypes composed a population around western Ireland; however, unique haplotypes

320 were not apparent in other species analysed in this study with similar sampling coverage (e.g.

321 Labrus bergylta, Palinurus elephas and Pelvetia canaliculata). A discrepancy in genetic

322 structure between species at this spatial scale has also been observed between two temperate

323 octocoral species (Eunicella verrucosa and Alcyonium digitatum) using microsatellite markers,

324 whereby northwest Ireland samples were found to be genetically isolated from other northeast

325 Atlantic samples in E. verrucosa, but not in A. digitatum (Holland, Jenkins \& Stevens, 2017).

326 This suggests that historical/contemporary gene flow between areas in the northeast Atlantic and

327 western Ireland is likely possible, but in some cases the spatial patterns of genetic structure could

328 be influenced by other processes such as strong selection pressures, species-specific life history 
329 traits, demographic fluctuations, and/or range expansions occurring at different times in different

330 species (Hellberg, 2009).

331

332 Demographic history

333 Demographic history was variable across species in the northeast Atlantic, as evidenced by both

334 the diverse structuring of the haplotype networks and the observed mismatch distributions within 335 species. The presence of one or more lineages and the complexity of mutational patterns in

336 several networks suggested some species have undergone pronounced changes in their

337 demography and genealogy. Connections with large mutation steps separating some haplotypes

338 are indicative of deep phylogenetic splits in the genealogies and suggests the persistence of old

339 populations in these species. Accumulating new mutations is a relatively slow process and,

340 therefore, sufficient time since coalescence must have elapsed to facilitate these large sequence

341 divergences (Avise 2009).

342 In the northeast Atlantic, the LGM has often been viewed as a possible explanation for

343 discrepancies in genealogies and for rapid population expansions via recolonisation as glaciers

344 started to retreat from their maximum positions (Hewitt, 2004). In this study, we detected rapid

345 expansions in many different taxa, of which the majority were estimated to occur after the LGM.

346 This supports evidence for post-LGM population expansions, possibly from periglacial refugia

347 (Maggs et al., 2008) or via recolonisation of areas previously affected by the Northern

348 Hemisphere ice sheets. These results are in contrast to the northeast Pacific where regional

349 persistence during the LGM appeared to be common in rocky-shore organisms (Marko et al.,

350 2010). The conclusions of several previous studies reanalysed in this meta-analysis also detected

351 rapid expansions (e.g. Jolly et al., 2006; Sotelo et al., 2008; Larmuseau et al., 2009); however, 
352 the authors of these studies estimated the dates of these expansions to have occurred pre-LGM.

353 This discrepancy could be due to the differences in mutation rates, whereby the original authors

354 typically used rates derived from ancient calibrations, while in this study we attempted to use

355 more recent calibration dates to correct for the potential time-dependency of molecular rates (Ho 356 et al., 2011).

357 Of course, we acknowledge that the signal of deviation from neutrality we detected may, 358 in some cases, be the result of a selective sweep and not a rapid expansion. This signal could be 359 distinguished by incorporating multi-locus data; nevertheless, given that a variety of species in

360 this study showed similar genealogical patterns consistent with demographic expansion, it seems

361 likely that most of them did indeed experience demographic changes associated with the end of

362 the LGM, rather than selective sweeps. Moreover, distinctive haplotypes were found in several

363 species networks (Pelvetia canaliculata, Pomatoschistus minutus, Owenia fusiformis and

364 Pectinaria koreni) to the south of where the Eurasian ice sheet is proposed to have extended

365 during the LGM (Fig. 1). This finding suggests populations of these species may have survived

366 in southern glacial refugia; though, as pointed out by some of the original authors, deep sequence

367 divergences in some species (e.g. O. fusiformis and P. korena) and the lack of a species-specific

368 molecular clock calibration makes inferences about refugia challenging (Jolly et al., 2005, 2006).

369 It is difficult to suggest an explanation for the two expansions estimated to have pre-dated

370 the LGM (using mismatch analysis), but which fall within the last glacial period. This pattern of

371 pre-LGM expansion has also been reported in a number of previous studies for a variety of

372 marine taxa (e.g. Hoarau et al., 2007; Marko et al., 2010; Ni et al., 2014; Almada et al., 2017).

373 One potential explanation for this pattern is that sea level during the last glacial cycle did not

374 decrease uniformly towards the level observed at the LGM, but oscillated rapidly over a period 
375 of $60 \mathrm{Ka}$ to $30 \mathrm{Ka}$ (see Fig. 3a in Lambeck et al., 2002). Therefore, it may be possible that we

376 are detecting the signature of a population expansion during one of these sudden increases in sea

377 level during the last glacial period. Alternatively, as the BSP analysis inferred a post-LGM

378 expansion for these two datasets, this could be a limitation associated with the mismatch analysis

379 approach, which does not consider genealogy, and may, therefore, produce a less precise

380 estimation. In addition, the sample of genetic diversity for this species/lineage may not be

381 representative (Karl et al., 2012) or the genetic signal we detected here may have been the result

382 of a selective sweep and not a rapid expansion.

383 The use of single marker mtDNA genealogies and coalescence theory can introduce

384 challenges associated with the interpretation of data and these limitations should be

385 acknowledged (Karl et al., 2012). For example, the populations under study may have

386 experienced multiple episodes of growth and decline; however, only the most recent population

387 expansion event can be detected using coalescence analysis and, in some cases, these events may

388 not be sufficiently severe to be detected (Karl et al., 2012). In addition, coalescent histories can

389 differ amongst loci because they can experience mutation and genetic drift independently.

390 Therefore, analysis of a single gene only gives insight into the coalescent history of that locus,

391 which may not always be representative of population history. Analysis of multiple loci and

392 genomic markers would help to alleviate these concerns, and would likely provide enhanced

393 resolution for exploring the phylogeography of northeast Atlantic marine fauna.

394 Although population expansions were detected in a number of species in this study and

395 also in the wider literature, populations of other marine species, including five from this study,

396 have been found to remain stable throughout the LGM. As previously reported, not all coastal

397 marine taxa appear prone to demographic changes during or after ice ages (Janko et al., 2007; 
398 Marko et al., 2010; Olsen et al., 2010). It is also important to acknowledge that earlier events in

399 the Pleistocene and more ancient events that pre-date the Pleistocene may have helped shape the 400 contemporary patterns of genealogical structure observed in this study.

401

402 Conclusion

403 The findings of this meta-analysis indicate that species in the northeast Atlantic do not show a 404 uniform pattern of phylogeography, but rather a mixture of complex contemporary genealogical 405 structure. Reanalysis of demographic histories indicated that a large proportion of the 406 species/lineages included in this study have experienced post-LGM expansions, supporting the 407 general expectation that rapid population expansions occurred after the LGM as the ice sheets 408 started to retreat (Hewitt, 2000, 2004). This suggests that regional extirpation during the LGM 409 appears to be a common biogeographic history for many northeast Atlantic marine taxa.

410 However, improvements in mutation rate estimates, as well as the incorporation of multi-locus 411 and genomic markers, would likely provide greater accuracy and resolution for overcoming the 412 challenges associated with single mtDNA genealogies, and for improving our understanding of 413 phylogeography in the northeast Atlantic Ocean.

414

\section{Acknowledgements}

416 We thank the many authors who kindly provided or contributed to the original datasets used in 417 the meta-analysis. We also thank SYW Ho (Sydney), CN Roterman (Oxford) and KF Thompson 418 (Exeter) for insightful comments on the manuscript, and GW Freeman (Exeter) for species 419 illustrations.

420

421 


\section{References}

423 Almada F., Francisco SM., Lima CS., FitzGerald R., Mirimin L., Villegas-Ríos D., Saborido-

424 Rey F., Afonso P., Morato T., Bexiga S., Robalo JI. 2017. Historical gene flow constraints in 425 a northeastern Atlantic fish: phylogeography of the ballan wrasse Labrus bergylta across its 426 distribution range. Royal Society Open Science 4:160773. DOI: 10.1098/rsos.160773.

427 Alvarado-Bremer JR., Vinas J., Mejuto J., Ely B., Pla C. 2005. Comparative phylogeography of 428 Atlantic bluefin tuna and swordfish: the combined effects of vicariance, secondary contact, 429 introgression, and population expansion on the regional phylogenies of two highly migratory 430 pelagic fishes. Molecular Phylogenetics and Evolution 36:169-187. DOI:

$431 \quad$ 10.1016/j.ympev.2004.12.011.

432 Avise JC. 2009. Phylogeography: retrospect and prospect. Journal of Biogeography 36:3-15. 433 DOI: 10.1111/j.1365-2699.2008.02032.x.

434 Avise JC., Arnold J., Ball RM., Bermingham E., Lamb T., Neigel JE., Reeb CA., Saunders NC. 435 1987. Intraspecific phylogeography: the mitochondrial DNA bridge between population 436 genetics and systematics. Annual Review of Ecology and Systematics 18:489-522. DOI: $437 \quad$ 10.1146/annurev.es.18.110187.002421.

438 Barido-Sottani J., Bošková V., Plessis LD., Kühnert D., Magnus C., Mitov V., Müller NF., 439 Pečerska J., Rasmussen DA., Zhang C., Drummond AJ., Heath TA., Pybus OG., Vaughan 440 TG., Stadler T. 2018. Taming the BEAST - a community teaching material resource for 441

442

443

444

445

446

447

448

449 BEAST 2. Systematic Biology 67:170-174. DOI: 10.1093/sysbio/syx060.

Becquet V., Simon-Bouhet B., Pante E., Hummel H., Garcia P. 2012. Glacial refugium versus range limit: conservation genetics of Macoma balthica, a key species in the Bay of Biscay (France). Journal of Experimental Marine Biology and Ecology 432-433:73-82. DOI: 10.1016/j.jembe.2012.07.008.

Bouckaert R., Heled J., Kühnert D., Vaughan T., Wu C-H., Xie D., Suchard MA., Rambaut A., Drummond AJ. 2014. BEAST 2: a software platform for Bayesian evolutionary analysis. PLoS Computational Biology 10:e1003537. DOI: 10.1371/journal.pcbi.1003537.

Chevolot M., Hoarau G., Rijnsdorp AD., Stam WT., Olsen JL. 2006. Phylogeography and 450 population structure of thornback rays (Raja clavata L., Rajidae). Molecular Ecology 451 15:3693-3705. DOI: 10.1111/j.1365-294X.2006.03043.x. 
452 Chiverrell RC., Thomas GSP. 2010. Extent and timing of the Last Glacial Maximum (LGM) in 453 Britain and Ireland: a review. Journal of Quaternary Science 25:535-549. DOI:

$454 \quad 10.1002 /$ jqs. 1404.

455 Clark P., Dyke A., Shakun J., Carlson A., Clark J., Wohlfarth B., Mitrovica J., Hostetler S., 456 McCabe M. 2009. The Last Glacial Maximum. Science 325:710-714. DOI:

$457 \quad 10.1126 /$ science.1172873.

458 Correia AT., Ramos A a., Barros F., Silva G., Hamer P., Morais P., Cunha RL., Castilho R. 459 2012. Population structure and connectivity of the European conger eel (Conger conger) 460 across the north-eastern Atlantic and western Mediterranean: integrating molecular and otolith 461 elemental approaches. Marine Biology 159:1509-1525. DOI: 10.1007/s00227-012-1936-3.

462 Coscia I., Mariani S. 2011. Phylogeography and population structure of European sea bass in the 463 464 465 466 467 468 469 470 471

472

473 474 475 476 477 478 479 480 481 north-east Atlantic. Biological Journal of the Linnean Society 104:364-377. DOI:

$$
\text { 10.1111/j.1095-8312.2011.01712.x. }
$$

Couceiro L., Barreiro R., Ruiz JM., Sotka EE. 2007. Genetic isolation by distance among populations of the netted dog whelk Nassarius reticulatus (L.) along the European Atlantic coastline. The Journal of Heredity 98:603-10. DOI: 10.1093/jhered/esm067.

Couceiro L., López L., Sotka EE., Ruiz JM., Barreiro R. 2012. Molecular data delineate cryptic Nassarius species and characterize spatial genetic structure of $N$. nitidus. Journal of the Marine Biological Association of the United Kingdom 92:1175-1182. DOI: 10.1017/S0025315411000816.

Coyer JA., Peters AF., Stam WT., Olsen JL. 2003. Post-ice age recolonization and differentiation of Fucus serratus L. (Phaeophyceae; Fucaceae) populations in Northern Europe. Molecular Ecology 12:1817-1829. DOI: 10.1046/j.1365-294X.2003.01850.x.

Crandall ED., Sbrocco EJ., DeBoer TS., Barber PH., Carpenter KE. 2012. Expansion dating: calibrating molecular clocks in marine species from expansions onto the Sunda Shelf following the Last Glacial Maximum. Molecular Biology and Evolution 29:707-719. DOI: $10.1093 / \mathrm{molbev} / \mathrm{msr} 227$.

Cuveliers EL., Larmuseau MHD., Hellemans B., Verherstraeten SLNA., Volckaert FAM., Maes GE. 2012. Multi-marker estimate of genetic connectivity of sole (Solea solea) in the NorthEast Atlantic Ocean. Marine Biology 159:1239-1253. DOI: 10.1007/s00227-012-1905-x. 
482 D’Arcy J., Mirimin L., FitzGerald R. 2013. Phylogeographic structure of a protogynous

483 hermaphrodite species, the ballan wrasse Labrus bergylta, in Ireland, Scotland, and Norway, 484 using mitochondrial DNA. ICES Journal of Marine Science 70:685-693.

485 Drummond AJ., Rambaut A., Shapiro B., Pybus OG. 2005. Bayesian coalescent inference of past 486 population dynamics from molecular sequences. Molecular Biology and Evolution 22:1185487 1192. DOI: $10.1093 / \mathrm{molbev} / \mathrm{msi103.}$

$488 \mathrm{Fu}$ YX. 1997. Statistical tests of neutrality of mutations against population growth, hitchhiking 489 and background selection. Genetics 147:915-925. DOI: genetics.org//147/2/915.

490 Gómez A., Hughes RN., Wright PJ., Carvalho GR., Lunt DH. 2007. Mitochondrial DNA 491 phylogeography and mating compatibility reveal marked genetic structuring and speciation in 492 the NE Atlantic bryozoan Celleporella hyalina. Molecular Ecology 16:2173-2188. DOI:

$493 \quad 10.1111 / \mathrm{j} .1365-294 X .2007 .03308 . x$.

494 Gysels ES., Hellemans B., Pampoulie C., Volckaert FAM. 2004. Phylogeography of the common 495 goby, Pomatoschistus microps, with particular emphasis on the colonization of the 496 Mediterranean and the North Sea. Molecular Ecology 13:403-417. DOI: 10.1046/j.1365497 294X.2003.02087.x.

498 Halanych KM., Vodoti ET., Sundberg P., Dahlgren TG. 2013. Phylogeography of the horse 499 mussel Modiolus modiolus. Journal of the Marine Biological Association of the United 500 Kingdom 93:1857-1869. DOI: 10.1017/S0025315413000404.

501 Harrison F. 2011. Getting started with meta-analysis. Methods in Ecology and Evolution 2:1-10. 502 DOI: 10.1111/j.2041-210X.2010.00056.x.

503 Harpending HC. 1994. Signature of ancient population growth in a low resolution mitochondrial 504 DNA mismatch distribution. Human Biology 66:591-600.

505 Hellberg ME. 2009. Gene flow and isolation among populations of marine animals. Annual 506 Review of Ecology, Evolution, and Systematics 40:291-310. DOI:

507 10.1146/annurev.ecolsys.110308.120223.

508 Hewitt GM. 1999. Post-glacial re-colonization of European biota. Biological Journal of the 509 Linnean Society 68:87-112. DOI: 10.1111/j.1095-8312.1999.tb01160.x.

510 Hewitt GM. 2000. The genetic legacy of the Quaternary ice ages. Nature 405:907-913.

511 Hewitt GM. 2004. Genetic consequences of climatic oscillations in the Quaternary. Philosophical 512 Transactions of the Royal Society B 359:183-195. DOI: 10.1098/rstb.2003.1388. 
513 Heyden S Von Der., Beger M., Toonen RJ., Juinio-meñez MA., Ravago-gotanco R., Fauvelot C.,

514 Bernardi G. 2014. The application of genetics to marine management. Bulletin of Marine

515 Sciences 90:1-36. DOI: 10.5343/bms.2012.1079.

516 Hickerson MJ., Carstens BC., Cavender-Bares J., Crandall KA., Graham CH., Johnson JB.,

517 Rissler L., Victoriano PF., Yoder AD. 2010. Phylogeography's past, present, and future: 10

518 years after Avise, 2000. Molecular Phylogenetics and Evolution 54:291-301. DOI:

$519 \quad$ 10.1016/j.ympev.2009.09.016.

520 Ho SYW., Saarma U., Barnett R., Haile J., Shapiro B. 2008. The effect of inappropriate

521 calibration: three case studies in molecular ecology. PLoS ONE 3:e1615. DOI:

522 10.1371/journal.pone.0001615.

523 Ho SYW., Lanfear R., Bromham L., Phillips MJ., Soubrier J., Rodrigo AG., Cooper A. 2011.

524 Time-dependent rates of molecular evolution. Molecular Ecology 20:3087-3101. DOI:

$525 \quad 10.1111 /$ j.1365-294X.2011.05178.x.

526 Hoarau G., Coyer JA., Veldsink JH., Stam WT., Olsen JL. 2007. Glacial refugia and

527 recolonization pathways in the brown seaweed Fucus serratus. Molecular Ecology 16:3606-

528 3616. DOI: $10.1111 /$ j.1365-294X.2007.03408.x.

529 Hofreiter M., Stewart J. 2009. Ecological change, range fluctuations and population dynamics

530 during the Pleistocene. Current Biology 19:R584-R594. DOI: 10.1016/j.cub.2009.06.030.

531 Holland LP., Jenkins TL., Stevens JR. 2017. Contrasting patterns of population structure and

532 gene flow facilitate exploration of connectivity in two widely distributed temperate

533 octocorals. Heredity 119:35-48. DOI: 10.1038/hdy.2017.14.

534 Hughes ALC., Gyllencreutz R., Lohne ØS., Mangerud J., Svendsen JI. 2016. The last Eurasian

535 ice sheets - a chronological database and time-slice reconstruction, DATED-1. Boreas 45:1-

536 45. DOI: 10.1111/bor.12142.

537 Janko K., Lecointre G., Devries A., Couloux A., Cruaud C., Marshall C. 2007. Did glacial

538 advances during the Pleistocene influence differently the demographic histories of benthic and

539 pelagic Antarctic shelf fishes? Inferences from intraspecific mitochondrial and nuclear DNA

540 sequence diversity. BMC Evolutionary Biology 7:220. DOI: 10.1186/1471-2148-7-220.

541 Jolly MT., Jollivet D., Gentil F., Thiébaut E., Viard F. 2005. Sharp genetic break between

542 Atlantic and English Channel populations of the polychaete Pectinaria koreni, along the north

543 coast of France. Heredity 94:23-32. DOI: 10.1038/sj.hdy.6800543. 
544 Jolly MT., Viard F., Gentil F., Thiébaut E., Jollivet D. 2006. Comparative phylogeography of 545 two coastal polychaete tubeworms in the Northeast Atlantic supports shared history and 546 vicariant events. Molecular Ecology 15:1841-1855. DOI: 10.1111/j.1365547 294X.2006.02910.x.

548 Jost L. 2008. $G_{\mathrm{ST}}$ and its relatives do not measure differentiation. Molecular Ecology 17:4015549 4026. DOI: $10.1111 /$ j.1365-294X.2008.03887.x.

550 Karl SA., Toonen RJ., Grant WS., Bowen BW. 2012. Common misconceptions in molecular 551 ecology: echoes of the modern synthesis. Molecular Ecology 21:4171-4189. DOI:

552 10.1111/j.1365-294X.2012.05576.x.

553

Keenan K., Mcginnity P., Cross TF., Crozier WW., Prodohl PA. 2013. DiveRsity: An R package 554 for the estimation and exploration of population genetics parameters and their associated 555 errors. Methods in Ecology and Evolution 4:782-788. DOI: 10.1111/2041-210X.12067.

556

557

558

559

560

561

562

563

564

565

566

567

568

569

570

571

572

573

Kelly RP., Palumbi SR. 2010. Genetic structure among 50 species of the northeastern pacific rocky intertidal community. PLoS ONE 5. DOI: 10.1371/journal.pone.0008594.

Krakau M., Jacobsen S., Jensen KT., Reise K. 2012. The cockle Cerastoderma edule at northeast Atlantic shores: genetic signatures of glacial refugia. Marine Biology 159:221-230. DOI: 10.1007/s00227-011-1802-8.

Laakkonen HM., Strelkov P., Väinölä R. 2015. Molecular lineage diversity and inter-oceanic biogeographical history in Hiatella (Mollusca, Bivalvia). Zoologica Scripta 44:383-402. DOI: 10.1111/zsc.12105.

Lambeck K., Chappell J. 2001. Sea level change through the last glacial cycle. Science 292:679686. DOI: $10.1126 /$ science.1059549.

Lambeck K., Esat TM., Potter E-K. 2002. Links between climate and sea levels for the past three million years. Nature 419:199-206. DOI: 10.1038/nature01089.

Larmuseau MHD., Van Houdt JKJ., Guelinckx J., Hellemans B., Volckaert FAM. 2009.

Distributional and demographic consequences of Pleistocene climate fluctuations for a marine demersal fish in the north-eastern Atlantic. Journal of Biogeography 36:1138-1151. DOI: 10.1111/j.1365-2699.2008.02072.x.

Librado P., Rozas J. 2009. DnaSP v5: A software for comprehensive analysis of DNA polymorphism data. Bioinformatics 25:1451-1452. DOI: 10.1093/bioinformatics/btp187. 
574 Liggins L., Treml EA., Possingham HP., Riginos C. 2016. Seascape features, rather than 575 dispersal traits, predict spatial genetic patterns in co-distributed reef fishes. Journal of 576 Biogeography 43:256-267. DOI: 10.1111/jbi.12647.

577 Maggs C., Castilho R., Foltz D., Henzler C., Jolly M., Kelly J., Olsen J., Perez K., Stam W., 578 Vainola R., Viard F., Wares J. 2008. Evaluating signatures of glacial refugia for North 579 Atlantic benthic marine taxa. Ecology 89:108-122.

580 Marko PB., Hoffman JM., Emme SA., McGovern TM., Keever CC., Nicole Cox L. 2010. The 581 "Expansion-Contraction" model of Pleistocene biogeography: rocky shores suffer a sea 582 change? Molecular Ecology 19:146-169. DOI: 10.1111/j.1365-294X.2009.04417.x.

583 Ménot G., Bard E., Rostek F., Weijers JWH., Hopmans EC., Schouten S., Sinninghe Damsté JS. 584 2006. Early reactivation of European rivers during the last deglaciation. Science 313:1623585 1625. DOI: 10.1126/science.1130511.

586 Neiva J., Assis J., Fernandes F., Pearson GA., Serrão EA. 2014. Species distribution models and 587

588 589

590

591

592

593

594

595

596

597

598

599

600

601

602

$603 \quad 10.1016 /$ j.ympev.2008.04.022. mitochondrial DNA phylogeography suggest an extensive biogeographical shift in the highintertidal seaweed Pelvetia canaliculata. Journal of Biogeography 41:1137-1148. DOI: 10.1111/jbi.12278.

Neiva J., Pearson GA., Valero M., Serrão EA. 2012. Drifting fronds and drifting alleles: range dynamics, local dispersal and habitat isolation shape the population structure of the estuarine seaweed Fucus ceranoides. Journal of Biogeography 39:1167-1178. DOI: 10.1111/j.13652699.2011.02670.x.

Ni G., Li Q., Kong L., Yu H. 2014. Comparative phylogeography in marginal seas of the northwestern Pacific. Molecular Ecology 23:534-548. DOI: 10.1111/mec.12620.

Olsen JL., Zechman FW., Hoarau G., Coyer JA., Stam WT., Valero M., Åberg P. 2010. The phylogeographic architecture of the fucoid seaweed Ascophyllum nodosum: an intertidal "marine tree" and survivor of more than one glacial-interglacial cycle. Journal of Biogeography 37:842-856. DOI: 10.1111/j.1365-2699.2009.02262.x.

Palero F., Abelló P., Macpherson E., Gristina M., Pascual M. 2008. Phylogeography of the European spiny lobster (Palinurus elephas): influence of current oceanographical features and historical processes. Molecular Phylogenetics and Evolution 48:708-717. DOI: 
604 Paradis E. 2010. Pegas: An R package for population genetics with an integrated-modular 605 approach. Bioinformatics 26:419-420. DOI: 10.1093/bioinformatics/btp696.

606 Patarnello T., Volckaert FAMJ., Castilho R. 2007. Pillars of Hercules: is the Atlantic607 Mediterranean transition a phylogeographical break? Molecular Ecology 16:4426-4444. DOI: $608 \quad 10.1111 /$ j.1365-294X.2007.03477.x.

609 Pelc RA., Warner RR., Gaines SD. 2009. Geographical patterns of genetic structure in marine 610 species with contrasting life histories. Journal of Biogeography 36:1881-1890. DOI: $611 \quad 10.1111 /$ j.1365-2699.2009.02138.x.

612 Provan J., Bennett KD. 2008. Phylogeographic insights into cryptic glacial refugia. Trends in 613 Ecology and Evolution 23:564-571. DOI: 10.1016/j.tree.2008.06.010.

614 Provan J., Wattier RA., Maggs CA. 2005. Phylogeographic analysis of the red seaweed Palmaria 615 palmata reveals a Pleistocene marine glacial refugium in the English Channel. Molecular 616 Ecology 14:793-803. DOI: 10.1111/j.1365-294X.2005.02447.x.

617 R Core Team. 2016. R: A language and environment for statistical computing. R Foundation for 618 Statistical Computing. Vienna, Austria. URL https://www.R-project.org/.

619 Rambaut A., Drummond AJ., Xie D., Baele G., Suchard MA. 2018. Posterior summarisation in 620 Bayesian phylogenetics using Tracer 1.7. Systematic Biology. DOI: 10.1093/sysbio/syy032.

621 Ramos-Onsins SE., Rozas J. 2002. Statistical properties of new neutrality tests against 622 population growth. Molecular Biology and Evolution 19:2092-2100. DOI: $623 \quad 10.1093 / \mathrm{molbev} / \mathrm{msl052}$.

624 Remerie T., Vierstraete A., Weekers PHH., Vanfleteren JR., Vanreusel A. 2009. Phylogeography 625 of an estuarine mysid, Neomysis integer (Crustacea, Mysida), along the north-east Atlantic 626 coasts. Journal of Biogeography 36:39-54. DOI: 10.1111/j.1365-2699.2008.01970.x. 627 Riginos C., Douglas KE., Jin Y., Shanahan DF., Treml EA. 2011. Effects of geography and life 628 history traits on genetic differentiation in benthic marine fishes. Ecography 34:566-575. DOI: $629 \quad 10.1111 /$ j.1600-0587.2010.06511.x.

630 Roman J., Palumbi SR. 2004. A global invader at home: population structure of the green crab, 631 Carcinus maenas, in Europe. Molecular Ecology 13:2891-2898. DOI: 10.1111/j.1365632 294X.2004.02255.x. 
633 Selkoe KA., Toonen RJ. 2011. Marine connectivity: a new look at pelagic larval duration and 634 genetic metrics of dispersal. Marine Ecology Progress Series 436:291-305. DOI: $635 \quad 10.3354 /$ meps09238.

636 Siegel DA., Kinlan BP., Gaylord B., Gaines SD. 2003. Lagrangian descriptions of marine larval 637 dispersion. Marine Ecology Progress Series 260:83-96. DOI: 10.3354/meps260083.

638 Sotelo G., Morán P., Fernández L., Posada D. 2008. Genetic variation of the spiny spider crab 639 Maja brachydactyla in the northeastern Atlantic. Marine Ecology Progress Series 362:211640 223. DOI: 10.3354/meps07433.

641 Taberlet P., Fumagalli L., Wust-Saucy A., Cossons J. 1998. Comparative phylogeography and 642 postglacial colonization routes in Europe. Molecular Ecology 7:453-464.

643 Tajima F. 1989. Statistical method for testing the neutral mutation hypothesis by DNA

644 polymorphism. Genetics 123:585-595. DOI: PMC1203831.

645 Toonen RJ., Andrews KR., Baums IB., Bird CE., Concepcion GT., Daly-Engel TS., Eble JA., 646 Faucci A., Gaither MR., Iacchei M., Puritz JB., Schultz JK., Skillings DJ., Timmers MA., 647 Bowen BW. 2011. Defining boundaries for ecosystem-based management: a multispecies 648 case study of marine connectivity across the Hawaiian Archipelago. Journal of Marine 649 Biology 2011:1-13. DOI: 10.1155/2011/460173.

650 Weersing K., Toonen R. 2009. Population genetics, larval dispersal, and connectivity in marine 651 systems. Marine Ecology Progress Series 393:1-12. DOI: 10.3354/meps08287.

652 Weir BS., Cockerham CC. 1984. Estimating $F$-statistics for the analysis of population structure. 653 Evolution 38:1358-1370. DOI: 10.2307/2408641.

654 


\section{Table $\mathbf{1}$ (on next page)}

List of the papers used in the meta-analysis and a summary of the information extracted from each study. 
1 Table 1: List of the papers used in the meta-analysis and a summary of the information extracted from each study.

\begin{tabular}{|c|c|c|c|c|c|c|}
\hline $\begin{array}{l}\text { Taxon } \\
\text { Species }\end{array}$ & $\begin{array}{l}\text { MtDNA } \\
\text { gene }\end{array}$ & $\begin{array}{c}\text { No. } \\
\text { sites; } \\
N\end{array}$ & $\begin{array}{l}\text { Sampling site } \\
\text { distribution }\end{array}$ & Larval development & $\begin{array}{l}\text { No. of } \\
\text { lineages }\end{array}$ & Reference \\
\hline \multicolumn{7}{|l|}{ Crustacean } \\
\hline Carcinus maenas & $\mathrm{COI}$ & $13 ; 200$ & SW Spain to Norway & PLD, long & 1 & $\begin{array}{l}\text { Roman \& Palumbi, } \\
2004\end{array}$ \\
\hline Maja brachydactyla & $\mathrm{COI}$ & $13 ; 291$ & $\begin{array}{l}\text { SW Spain to W Ireland } \\
\text { SW Spain to E }\end{array}$ & PLD, 2-3 wk & $\begin{array}{l}1 \\
1\end{array}$ & Sotelo et al., 2008 \\
\hline Neomysis integer & $\mathrm{COI}$ & $9 ; 379$ & $\begin{array}{l}\text { Scotland } \\
\text { S Portugal to } \mathrm{W}\end{array}$ & No PLD, brooder & 1 & Remerie et al., 2009 \\
\hline $\begin{array}{l}\text { Palinurus elephas } \\
\text { Fish }\end{array}$ & $\mathrm{COI}$ & $6 ; 119$ & Scotland & PLD, up to $1 \mathrm{yr}$ & & Palero et al., 2008 \\
\hline $\begin{array}{l}\text { Conger conger } \\
\text { Dicentrarchus } \\
\text { labrax }\end{array}$ & $\begin{array}{l}\mathrm{CR} \\
\mathrm{CR}\end{array}$ & $\begin{array}{l}4 ; 232 \\
9 ; 93\end{array}$ & $\begin{array}{l}\text { Azores to Ireland } \\
\text { Bay of Biscay to } \\
\text { Norway }\end{array}$ & $\begin{array}{l}\text { Leptocephalus, up to } 2 \\
\text { yr } \\
\text { PLD, 8-12 wk }\end{array}$ & $\begin{array}{l}1 \\
1\end{array}$ & $\begin{array}{l}\text { Correia et al., } 2012 \\
\text { Coscia \& Mariani, } \\
2011\end{array}$ \\
\hline $\begin{array}{l}\text { Labrus bergylta } \\
\text { Pomatoschistus }\end{array}$ & $\mathrm{CR}$ & $7 ; 279$ & $\begin{array}{l}\text { W Ireland to Norway } \\
\text { Bay of Biscay to }\end{array}$ & PLD, 37-49d & $\begin{array}{l}1 \\
1\end{array}$ & D'Arcy et al., 2013 \\
\hline $\begin{array}{l}\text { microps } \\
\quad \text { Pomatoschistus }\end{array}$ & Cyt $b$ & $10 ; 232$ & Norway & PLD, 6-9 wk & 1 & $\begin{array}{l}\text { Gysels et al., } 2004 \\
\text { Larmuseau et al., }\end{array}$ \\
\hline minutus & Cyt $b$ & $8 ; 165$ & S Portugal to Norway & PLD, unknown & & 2009 \\
\hline Raja clavata & Cyt $b$ & $9 ; 315$ & $\begin{array}{l}\text { Azores to North Sea } \\
\text { Bay of Biscay to }\end{array}$ & No PLD, oviparous & $\begin{array}{l}1 \\
1\end{array}$ & Chevolot et al., 2006 \\
\hline Solea solea & Cyt $b$ & $10 ; 645$ & $\begin{array}{l}\text { Skagerrak } \\
\text { S Portugal to }\end{array}$ & PLD, up to $3 \mathrm{wk}$ & 1 & Cuveliers et al., 2012 \\
\hline $\begin{array}{l}\text { Symphodus melops } \\
\text { Macroalgae }\end{array}$ & $\mathrm{CR}$ & $10 ; 263$ & Skagerrak & PLD, $14-25 \mathrm{~d}$ & & Robalo et al., 2011 \\
\hline $\begin{array}{l}\quad \text { Pelvetia } \\
\text { canaliculata } \\
\text { Mollusc }\end{array}$ & IGS & $15 ; 429$ & Portugal to Norway & $\begin{array}{l}\text { No PLD, external } \\
\text { fertilisation }\end{array}$ & 1 & Neiva et al., 2014 \\
\hline Cerastoderma edule & COI & $12 ; 300$ & $\begin{array}{l}\text { Portugal to Norway } \\
\text { Bay of Biscay to North }\end{array}$ & PLD, up to $4 \mathrm{wk}$ & $\begin{array}{l}1 \\
2\end{array}$ & Krakau et al., 2012 \\
\hline Macoma balthica & $\mathrm{COI}$ & $15 ; 339$ & Sea & PLD, 2-5 wk & & Becquet et al., 2012 \\
\hline Modiolus modiolus & COI & $4 ; 73$ & Irish Sea to Norway & PLD, up to $24 \mathrm{wk}$ & 2 & Halanych et al., 2013 \\
\hline $\begin{array}{l}\text { Nassarius nitidus } \\
\text { Nassarius }\end{array}$ & $\mathrm{COI}$ & $3 ; 62$ & NW Spain to Sweden & PLD, 4-8 wk & $\begin{array}{l}1 \\
1\end{array}$ & Couceiro et al., 2012 \\
\hline reticulatus & COI & $6 ; 156$ & S Portugal to UK & PLD, 4-8 wk & & Couceiro et al., 2007 \\
\hline
\end{tabular}




\section{Polychaete}

Owenia fusiformis

Pectinaria koreni

COI

$11 ; 283$

Portugal to North Sea

PLD, up to $28 \mathrm{~d}$

PLD, up to $15 \mathrm{~d}$

3

Other

Celleporella hyalina

COI

9; 63 NW Spain to Iceland PLD, 1-4 hr

Jolly et al., 2006

Jolly et al., 2006

MtDNA, mitochondrial DNA; $N$, total number of sequenced individuals; PLD, pelagic larval duration. 


\section{Table 2 (on next page)}

Summary statistics for each species.

Population differentiation and demographic statistics are shown. In all statistical tests, significance was assessed using 10,000 permutations / bootstrap replicates. 
Table 2: Summary statistics for each species. Population differentiation and demographic statistics are shown. In all statistical tests, significance 2 was assessed using 10,000 permutations / bootstrap replicates.

\begin{tabular}{|c|c|c|c|c|c|c|c|}
\hline \multirow{2}{*}{ Species } & \multicolumn{2}{|c|}{ Population differentiation } & \multicolumn{5}{|c|}{ Demography } \\
\hline & Jost's $D$ & $F_{\mathrm{ST}}$ & Tajima's $D$ & $F_{\mathrm{S}}$ & $\boldsymbol{R}_{2}$ & $r$ & Expansion \\
\hline \multicolumn{8}{|l|}{ Crustacean } \\
\hline Carcinus maenas & $0.584 * * *$ & $0.157 * * *$ & $-1.73^{*}$ & $-40.36^{* * *}$ & $0.034 *$ & 0.018 & Yes \\
\hline Maja brachydactyla & $0.298 * * *$ & $0.045 * * *$ & $-1.86 * *$ & $-33.72 * * *$ & $0.028 *$ & 0.030 & Yes \\
\hline Neomysis integer & $0.956 * * *$ & $0.554 * * *$ & 0.14 & -0.954 & 0.024 & 0.086 & No \\
\hline Palinurus elephas & 0.023 & -0.008 & $-2.31 * * *$ & $-30.19 * * *$ & $0.019 *$ & 0.094 & Yes \\
\hline \multicolumn{8}{|l|}{ Fish } \\
\hline Conger conger & 0.124 & -0.001 & $-2.58 * * *$ & $-211.1 * * *$ & $0.012 * * *$ & 0.031 & Yes \\
\hline Dicentrarchus labrax & $0.540^{*}$ & $0.031 *$ & $-1.88 * *$ & $-21.52 * * *$ & $0.047 *$ & 0.011 & Yes \\
\hline Labrus bergylta & $0.672 * * *$ & $0.135 * * *$ & -0.53 & $-49.35 * * *$ & 0.074 & 0.024 & Yes \\
\hline Pomatoschistus microps & $0.391 * * *$ & $0.385 * * *$ & -1.39 & $-17.90 * * *$ & 0.044 & 0.215 & Yes \\
\hline Pomatoschistus minutus & $0.652 * * *$ & $0.100 * * *$ & $-1.96 * *$ & $-90.56 * * *$ & $0.034^{*}$ & 0.015 & Yes \\
\hline Raja clavata & $0.375 * * *$ & $0.330 * * *$ & -0.09 & -2.340 & 0.076 & 0.309 & No \\
\hline Solea solea & 0.049 & 0.002 & $-2.02 * * *$ & $-131.9 * * *$ & $0.021 * *$ & 0.221 & Yes \\
\hline Symphodus melops & $0.578 * * *$ & $0.349 * * *$ & $-1.70^{*}$ & $-50.52 * * *$ & $0.032 *$ & 0.086 & Yes \\
\hline \multicolumn{8}{|l|}{ Macroalgae } \\
\hline Pelvetia canaliculata & $0.689 * * *$ & $0.482 * * *$ & $-1.53^{*}$ & $-19.02 * * *$ & 0.036 & 0.043 & Yes \\
\hline \multicolumn{8}{|l|}{ Mollusc } \\
\hline Cerastoderma edule & $0.662 * * *$ & $0.304 * * *$ & $-2.24 * * *$ & $-34.47 * * *$ & $0.019 * *$ & 0.033 & Yes \\
\hline Macoma balthica & $0.702 * * *$ & $0.470 * * *$ & - & - & - & - & - \\
\hline lineage 1 & - & - & -0.80 & -3.773 & 0.053 & 0.241 & No \\
\hline lineage 2 & - & - & -0.99 & -1.110 & 0.089 & 0.173 & No \\
\hline Modiolus modiolus ${ }^{\mathrm{a}}$ & 0.083 & $<0.001$ & $-1.79 *$ & $-11.91 * * *$ & $0.045^{*}$ & 0.156 & Yes \\
\hline Nassarius nitidus & $0.222 * * *$ & $0.302 * * *$ & $-1.49 *$ & 0.028 & $0.049 *$ & 0.446 & No \\
\hline Nassarius reticulatus & 0.047 & -0.003 & $-2.51 * * *$ & $-48.33 * * *$ & $0.016 * *$ & 0.080 & Yes \\
\hline \multicolumn{8}{|l|}{ Polychaete } \\
\hline Owenia fusiformis & $0.788 * * *$ & $0.055 * * *$ & - & - & - & - & - \\
\hline lineage 1 & - & - & $-2.34 * * *$ & $-114.8 * * *$ & $0.024 * *$ & 0.020 & Yes \\
\hline lineage 2 & - & - & $-2.06 * *$ & $-55.00 * * *$ & $0.030 * *$ & $0.008 * *$ & Yes \\
\hline lineage 3 & - & - & -1.26 & $-3.934 * *$ & 0.084 & 0.080 & Yes \\
\hline Pectinaria koreni & $0.596 * * *$ & $0.112 * * *$ & - & - & - & - & - \\
\hline lineage 1 & - & - & $-1.99 * *$ & $-76.48 * * *$ & $0.027 * *$ & 0.021 & Yes \\
\hline lineage 2 & - & - & $-2.63 * * *$ & $-54.02 * * *$ & $0.018 * * *$ & $0.029 *$ & Yes \\
\hline
\end{tabular}


Other

Celleporella hyalina

$0.513^{* * *} \quad 0.488^{* * *}$

$-1.35$

$-0.554$

0.063

0.061

No

$3 *<0.05, * *<0.01, * * *<0.001$.

$4 \quad F_{\mathrm{s}}$, Fu's $F_{\mathrm{s}} ; R_{2}$, Ramos-Onsins' $R_{2} ; r$, Harpending's raggedness index.

5 a Only statistics for lineage 1 are shown. 


\section{Figure 1}

Topographical map of the northeast Atlantic Ocean.

The white dotted lines represent the maximum extent of ice cover during the Last Glacial Maximum (LGM) (redrawn from Hughes et al., 2016). Orange lines indicate putative refugia: Hurd Deep, Brittany Peninsula and Iberia.

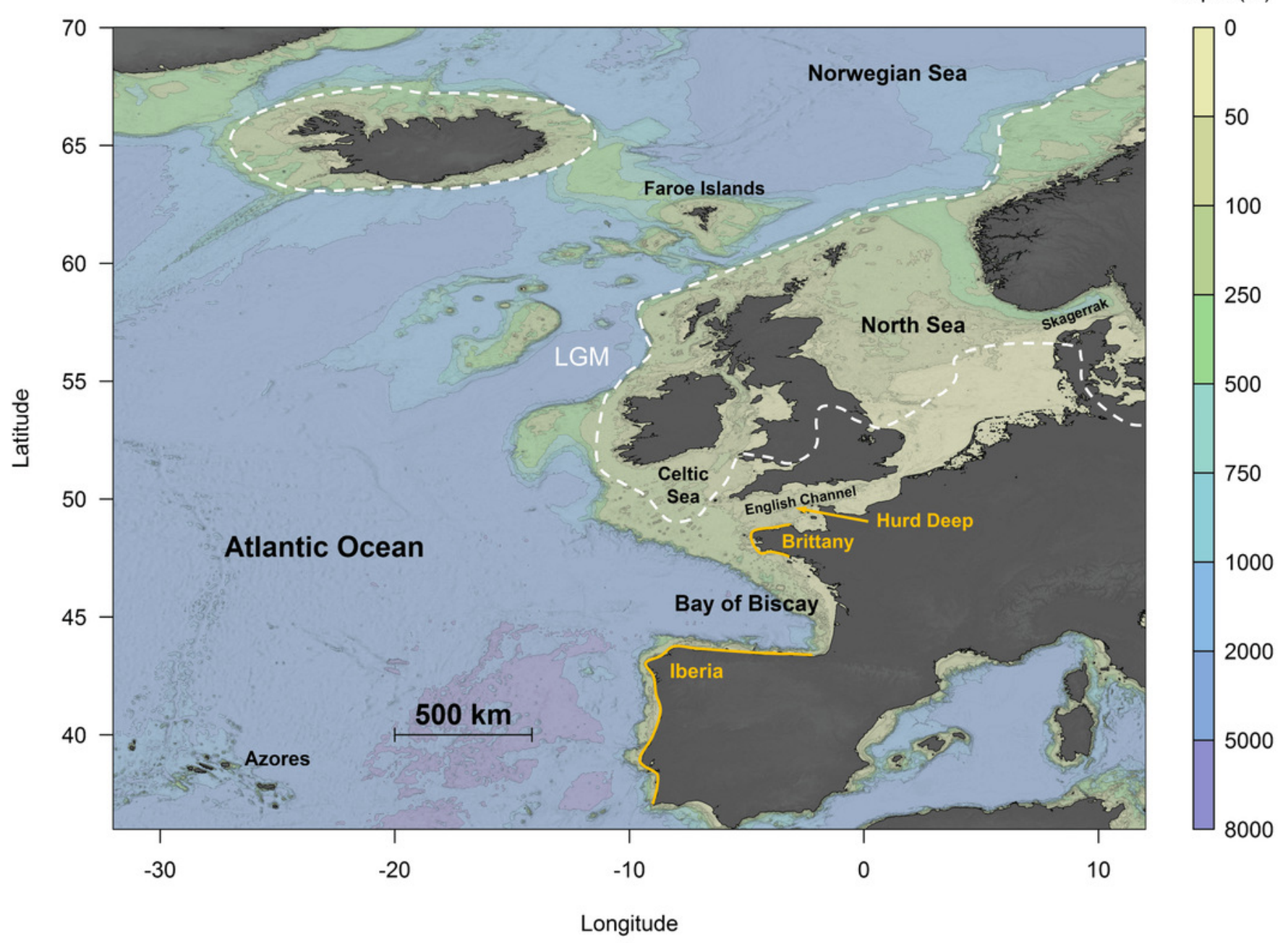




\section{Figure 2}

Haplotype networks showing four different network structures.

Haplotype networks showing (a) 'star' (Palinurus elephas), (b) 'complex star' (Carcinus maenas), (c) 'reciprocally monophyletic' (Macoma balthica) and (d) 'complex mutational' (Dicentrarchus labrax) structures. Each circle represents a unique haplotype and the sizes of the circles are proportional to the haplotype frequencies for each network but are not comparable across studies. Each line represents one mutation step and two or more steps are indicated by bars or numbers. Colours inside the circles correspond to sites which have individuals represented in that particular haplotype. Species illustrations by Guy Freeman. 
(a)

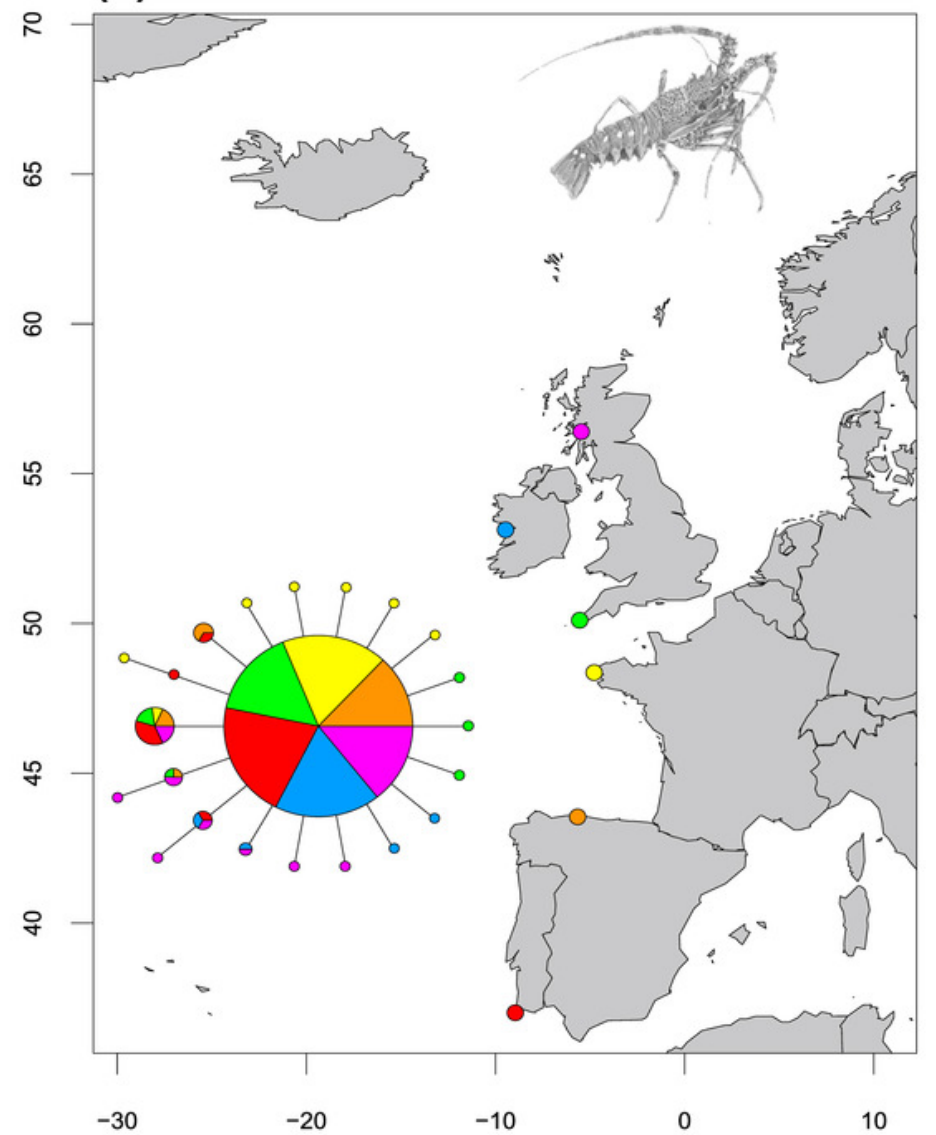

(c)

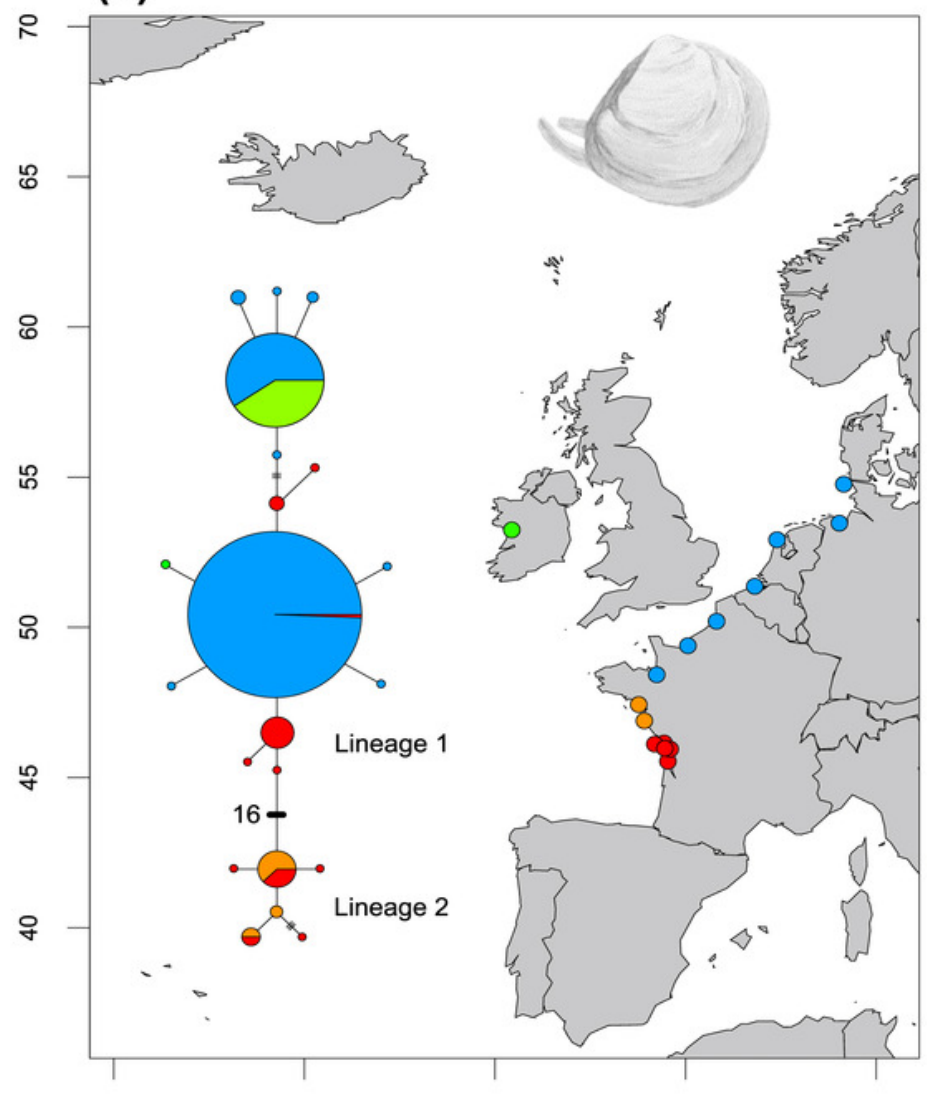

$-30$

$-20$

$-10$

0

10

PeerJ reviewing PDF | (2018:05:28381:2:0:NEW 19 Aug 2018) (b)

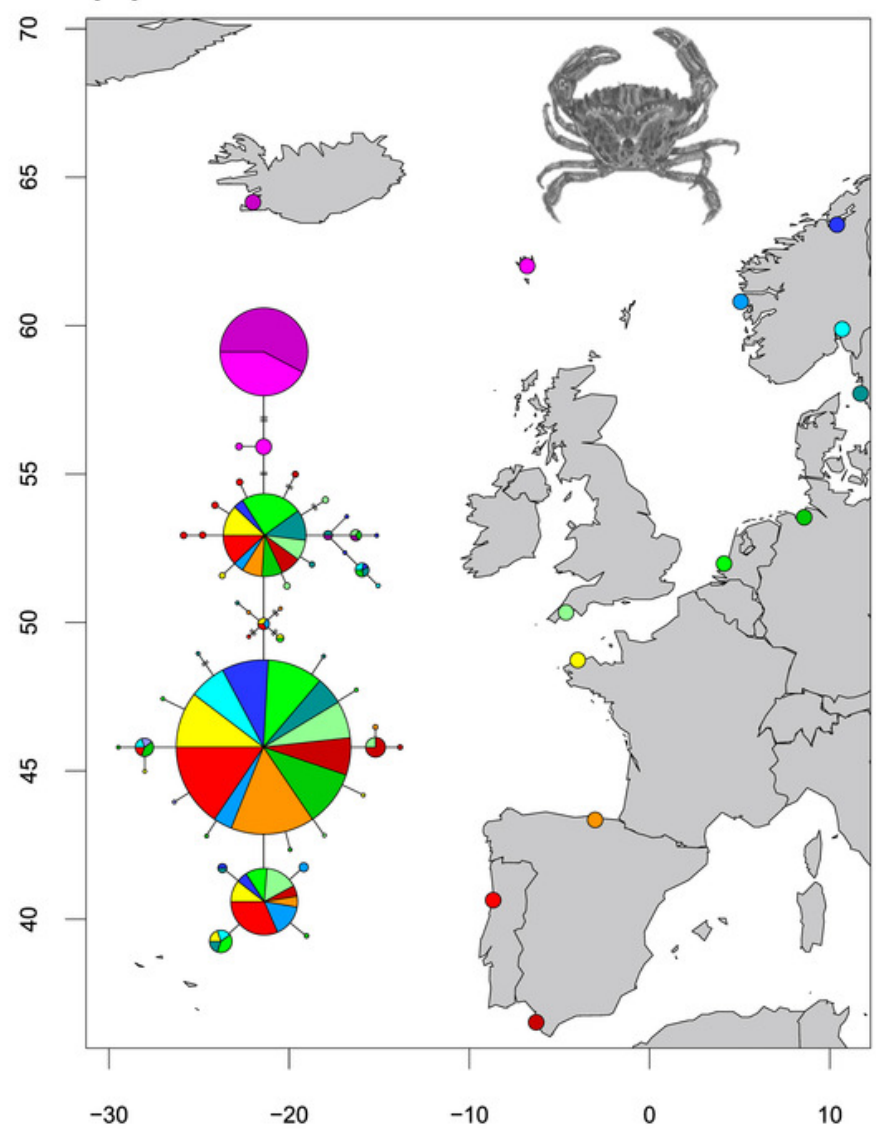

(d)

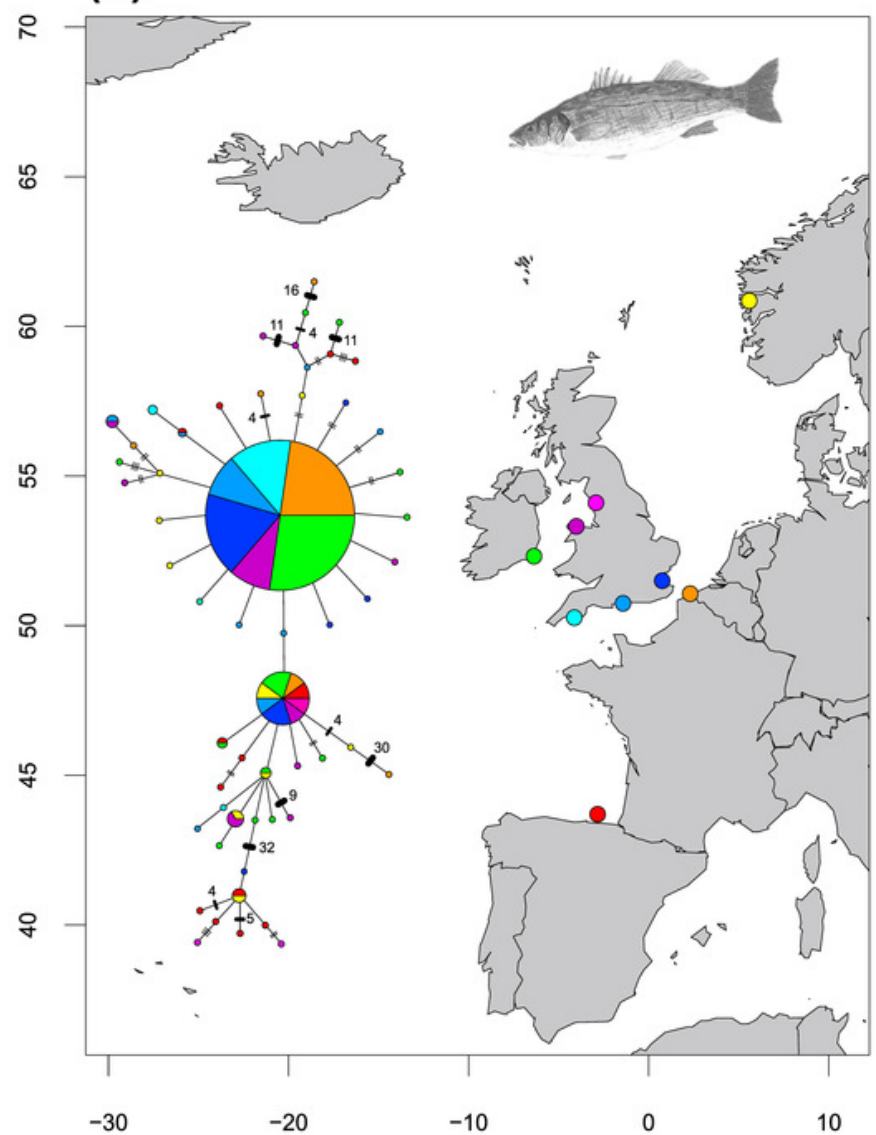




\section{Figure 3}

Mismatch distributions showing four different distributions.

Mismatch distributions showing (a) unimodal (Maja brachydactyla), (b) skewed unimodal (Nassarius reticulatus), (c) multimodal (Labrus bergylta) and (d) bimodal (Macoma balthica). Unimodal and skewed unimodal distributions are generally associated with a sudden expansion and a recent sudden expansion, respectively. Multimodal and bimodal are thought to be associated with a constant population size (but see text). Bars represent the frequency of pairwise nucleotide differences between individuals. Curves correspond to the expected distribution fitted to the data under a model of constant population size (solid line) or demographic expansion (dotted line). Species illustrations by Guy Freeman.

(a)

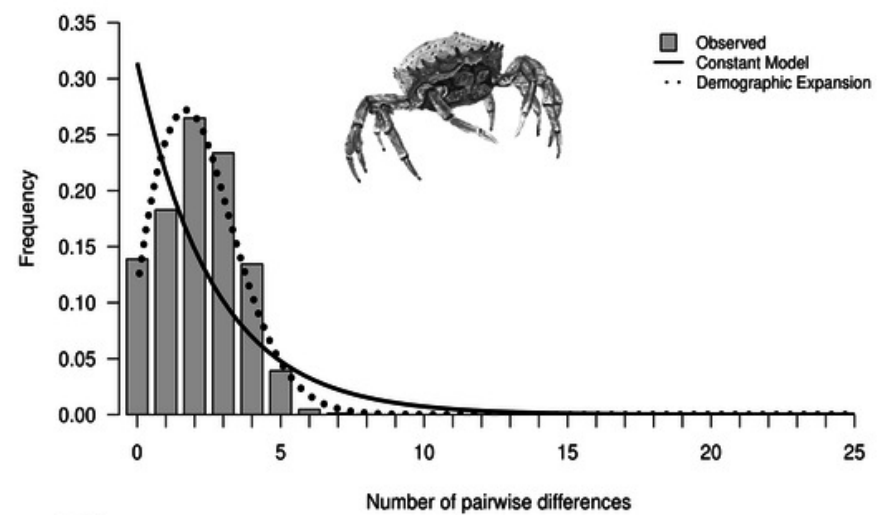

(c)

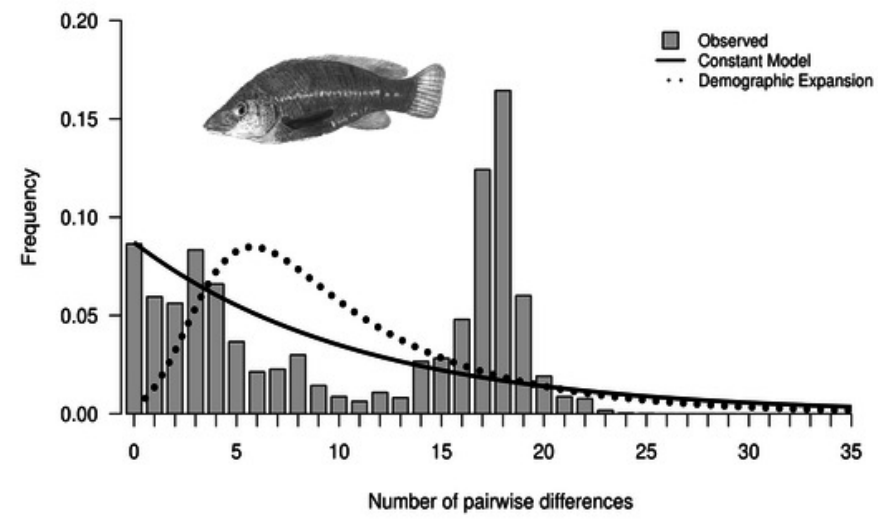

(b)

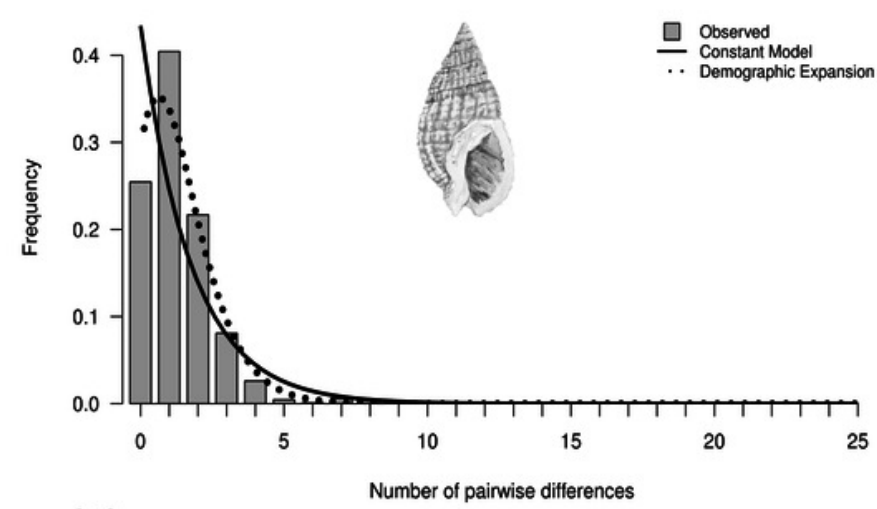

(d)

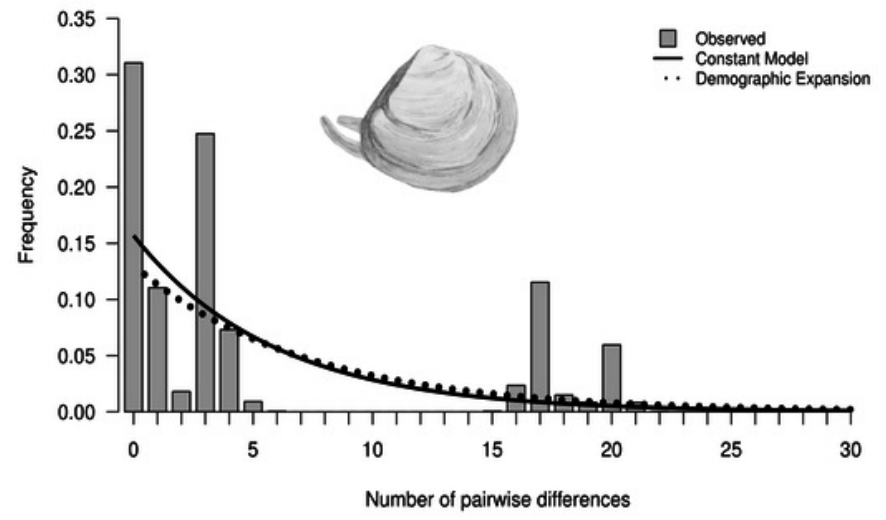




\section{Figure 4}

Estimated dates of expansion for species or lineages (L).

Estimated dates of expansion for species or lineages $(\mathrm{L})$ in which the demographic expansion hypothesis was not rejected. A minimum and maximum time since expansion is plotted as horizontal bars for some datasets, estimated from a minimum and maximum mutation rate (Table S1, Supporting information). The beginning of the last glacial period (dotted line) and the estimated time-frame of the Last Glacial Maximum (grey shaded area) are displayed. Species are organised by taxa: crustaceans, Carcinus maenas - Palinurus elephas); fish, Conger conger - Symphodus melops; macroalgae, Pelvetia canaliculata; molluscs, Cerastoderma edule - Nassarius reticulatus; polychaetes, Owenia fusiformis - Pectinaria koreni. Species illustrations by Guy Freeman. 


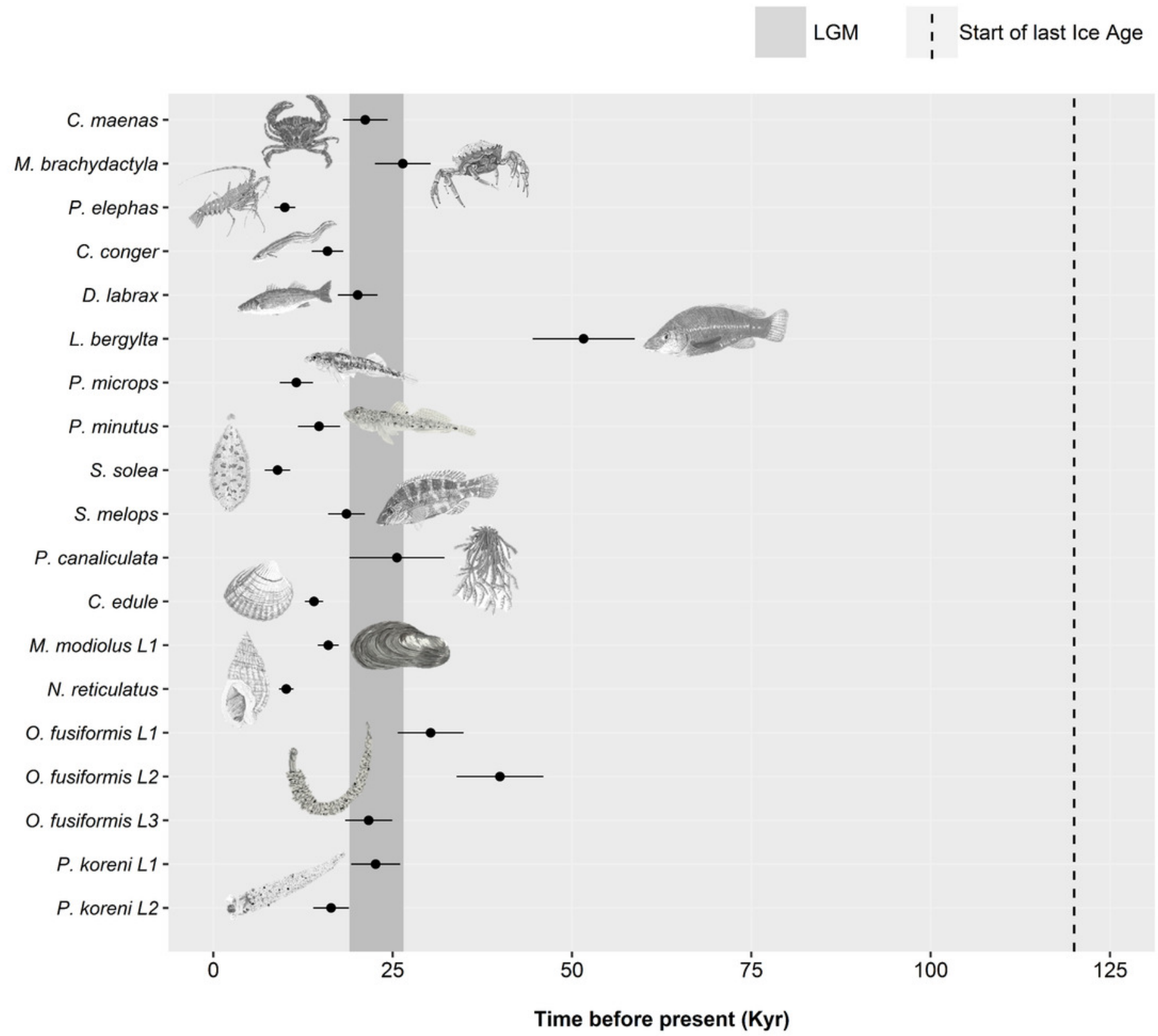




\section{Figure $\mathbf{5}$ (on next page)}

Bayesian Skyline Plots for species or lineages (L).

Bayesian Skyline Plots for species or lineages $(L)$ in which the demographic expansion hypothesis was not rejected. Solid black lines show the medium effective population size over time $\left(N_{\mathrm{e}}=\right.$ effective population size and $T=$ generation time); dashed black lines represent the $95 \%$ confidence intervals. The estimated time-frame of the Last Glacial Maximum is denoted by the area shaded grey. Species are organised by taxa: crustaceans, Carcinus maenas [A], Maja brachydactyla [B], Palinurus elephas [C]; fish, Conger conger [D], Dicentrarchus labrax [E], Labrus bergylta [F], Pomatoschistus microps [G], P. minutus [H], Solea solea [I], Symphodus melops [J]; macroalgae, Pelvetia canaliculata [K]; molluscs, Cerastoderma edule [L], Modiolus modiolus Lineage 1 [M], Nassarius reticulatus [N]; polychaetes, Owenia fusiformis Lineage 1 [O], $O$.

fusiformis Lineage 2 [P], O. fusiformis Lineage 3 [Q], Pectinaria koreni Lineage 1 [R], P. koreni Lineage 2 [S]. 
A
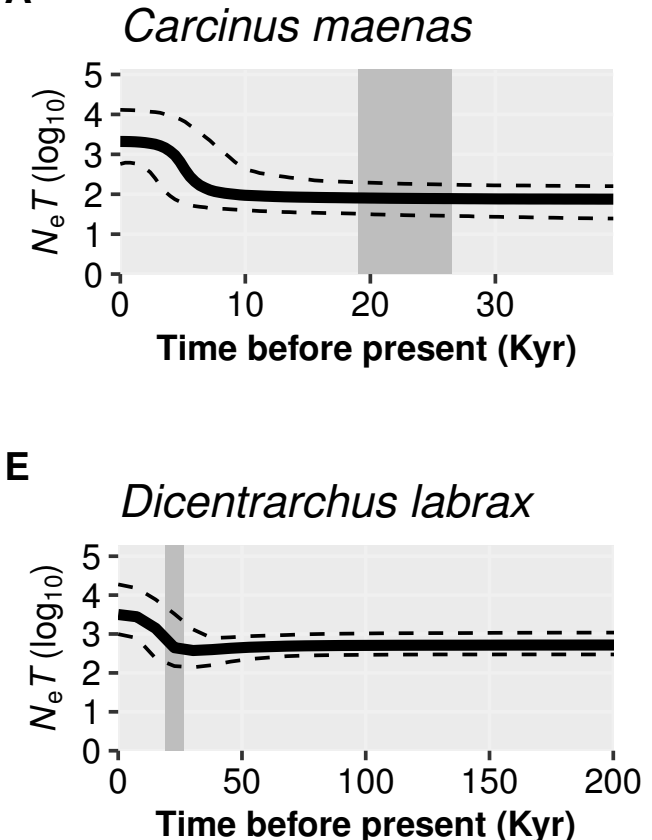

$\mathbf{I}$

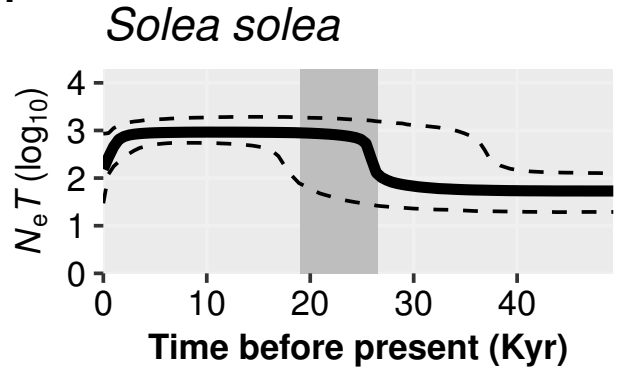

M

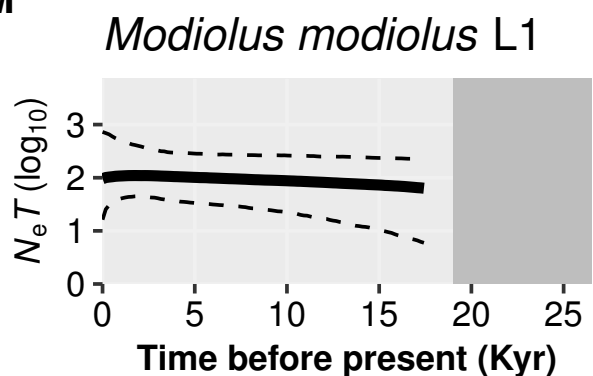

$\mathbf{Q}$

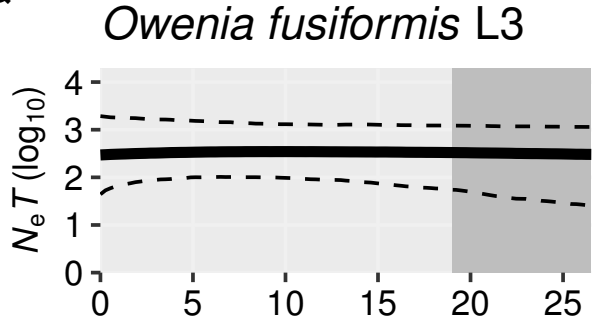

Time before present (Kyr)
B

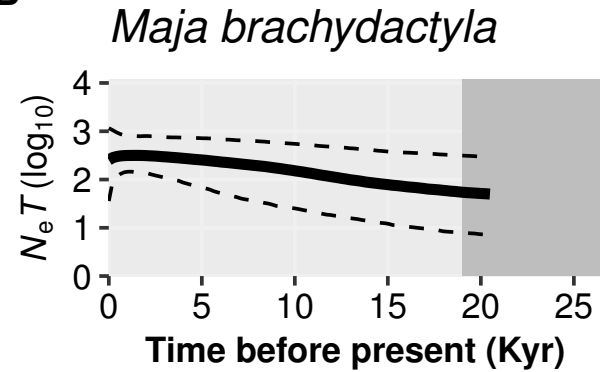

$\mathbf{F}$

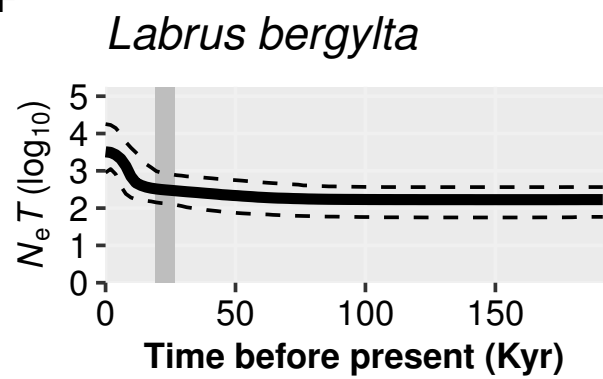

J

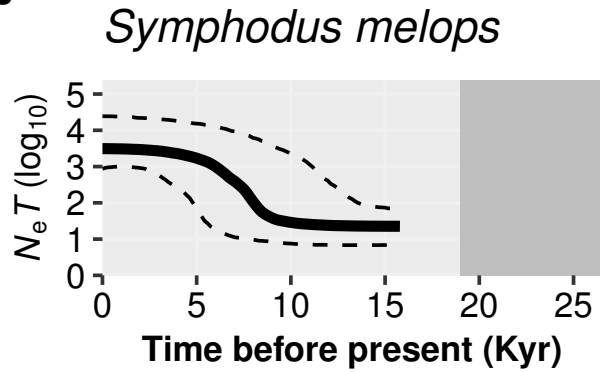

$\mathbf{N}$

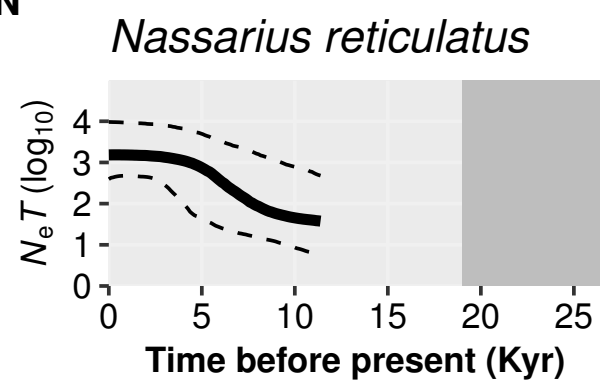

$\mathbf{R}$

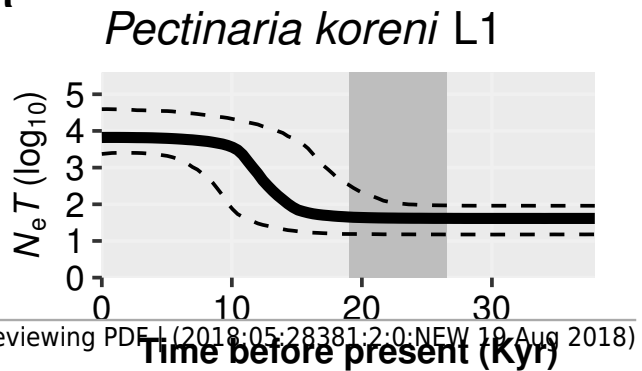

Palinurus elephas

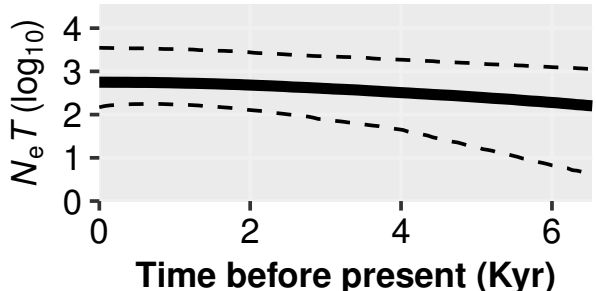

G

Pomatoschistus microps

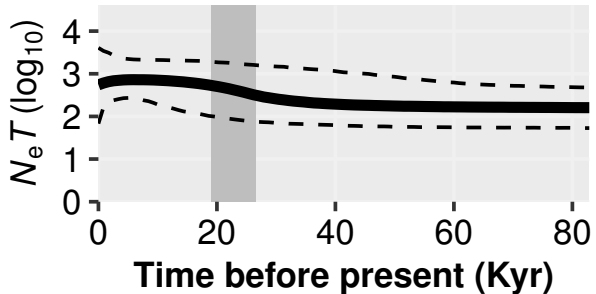

K

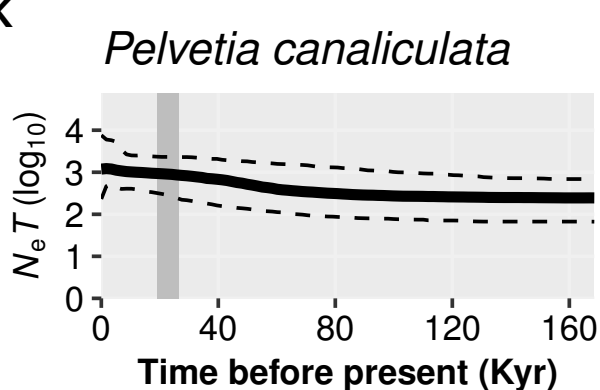

0

Owenia fusiformis $\mathrm{L} 1$

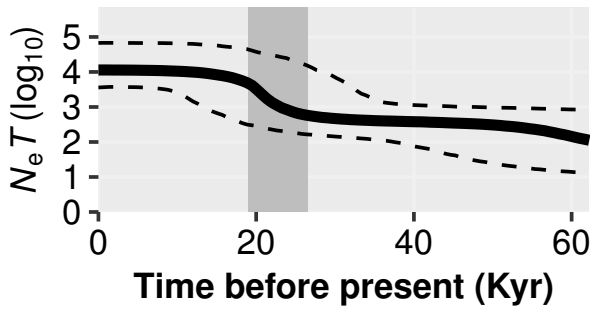

S

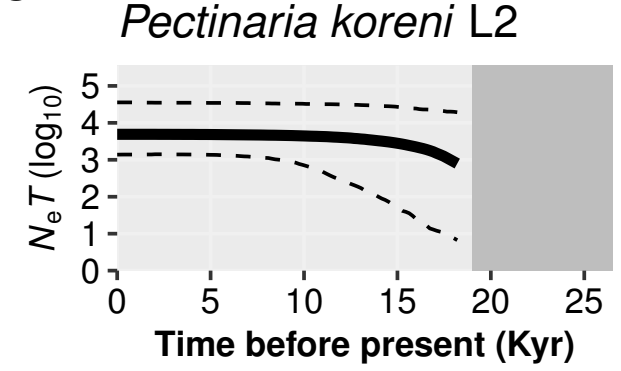

Conger conger

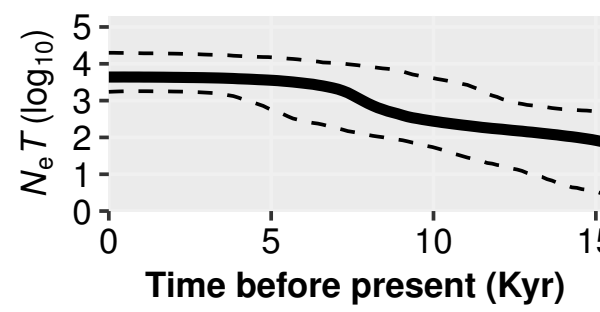

H

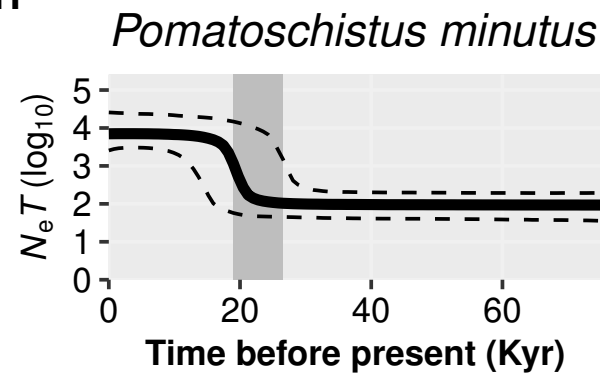

$\mathbf{L}$

\section{Cerastoderma edule}

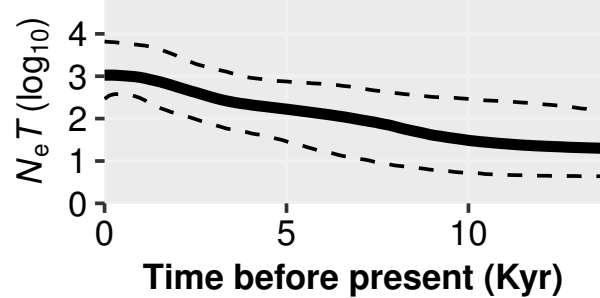

\section{Owenia fusiformis L2}

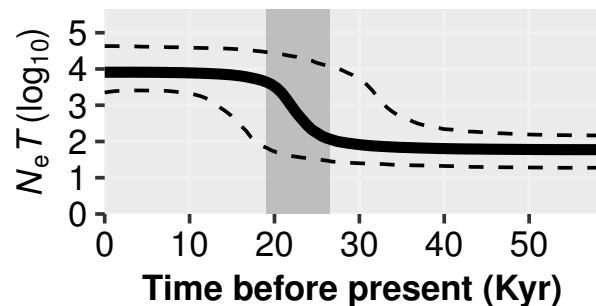

